\title{
Staatsveiligheid, strafvordering en strafproces
}

\author{
Alain Winants ${ }^{1}$
}

Daar waar men dient vast te stellen dat de publieke opinie een vrij goed - alhoewel soms vertekend en gekleurd - beeld heeft van de bevoegdheden en de werking van politiediensten en gerechtelijke overheden, dringt een radicaal tegengestelde conclusie zich op wanneer het gaat om de activiteiten van inlichtingen- en veiligheidsdiensten waarover vele misverstanden, misvattingen en zelfs mythes bestaan. Er dient zelfs te worden vastgesteld dat deze verkeerde beeldvorming, die soms kan grenzen aan fantasmen, tot in bepaalde politieke beleidskringen bestaat of minstens - waarschijnlijk om politieke motieven - onderhouden wordt. ${ }^{2}$

Het past hierbij evenwel ook in eigen boezem te kijken.

Inlichtingen- en veiligheidsdiensten overal ter wereld hebben niet als eerste roeping hun werking, hun activiteiten, hun competenties en hun middelen in de openbaarheid te brengen en geheimhouding is een onlosmakelijk gegeven dat verbonden is met deze diensten. Deze geheimhouding heeft echter een neveneffect, namelijk het 'ongekend is onbemind' syndroom dat uiteraard bijdraagt tot het in stand houden van de waanideeën over wat 'geheime diensten' nu exact doen.

Wellicht stelt men om deze reden dan ook vast dat verschillende van deze diensten, in meer of in mindere mate, een communicatiestrategie trachten uit te bouwen en zich bewust zijn van het belang van het imago van de inlichtingendiensten. ${ }^{3}$

Anderzijds dient ook te worden onderstreept dat heden ten dage de organisatie, de bevoegdheden en de opdrachten van inlichtingen- en veiligheidsdiensten nagenoeg in de meeste landen wettelijk geregeld zijn en dus in een bepaalde mate

I. De auteur is advocaat-generaal bij het Hof van Beroep te Brussel en sedert oktober 2006 aangewezen in de hoedanigheid van administrateur-generaal van de Veiligheid van de Staat. Ook is hij praktijklector strafrecht en strafprocesrecht aan de Vrije Universiteit te Brussel.

2. De op het ogenblik van het opstellen van dit preadvies aan de gang zijnde debatten in de Commissie van Justitie van de Senaat over de BIM-wetgeving (zie infra) zijn hiervan een perfecte illustratie.

3. Afhankelijk van de dienst en de concrete situatie kan het gaan om een reactieve strategie (antwoord wanneer een vraag wordt gesteld uitgaande van de pers), een proactieve strategie (regelmatig backgroundinformatie geven op initiatief van de inlichtingendienst) of een offensieve strategie (gebruik maken van de media om eigen doelstellingen te verwezenlijken). 
openbaar. ${ }^{4}$ Daarenboven is het ook zo dat nagenoeg alle Europese inlichtingen- en veiligheidsdiensten onderworpen zijn aan één of andere vorm van parlementaire of onafhankelijke controle door toezichtsorganen, ${ }^{5}$ hetgeen tot gevolg heeft dat hun werking, de problematieken waarmee ze geconfronteerd worden en de knelpunten vaak zijn opgenomen in openbare verslagen, die aangevuld met de jaarraporten en de fenomeenanalyses uitgaande van de diensten zelf toch een vrij correct beeld kunnen geven van het reilen en zeilen van inlichtingen- en veiligheidsdiensten.

Die openbaarheid heeft evenwel haar grenzen of moet alleszins aan bepaalde voorwaarden van discretie, confidentialiteit, classificatie en machtiging worden onderworpen of in het geval van het gebruik van informatie in gerechtelijke procedures aan de eerbiediging van bepaalde duidelijke nationale en internationale regels,algemene principes en in de intelligence community als universeel gangbaar aanvaarde normen.

Openbaarheid betekent met andere woorden niet totale transparantie, zoals democratische controle ook niet inhoudt dat informaties die worden meegedeeld onder bepaalde strikte voorwaarden van discretie en waarvan de bekendmaking door hun aard zelf een bedreiging kan vormen voor bepaalde personen/instellingen, in de pers en andere media worden publiek gemaakt.

Deze problematiek overtreft uiteraard het kader van dit preadvies, maar zij is wel illustratief voor het feit dat de werking van inlichtingen- en veiligheidsdiensten vaak gepaard gaat met spanningsvelden waarop zich zo niet onverenigbare dan toch wel tegengestelde belangen bewegen.

\section{De Belgische inlichtingen- en veiligheidsdiensten}

\section{I Algemene opmerkingen}

Zoals reeds hiervoor uiteengezet, geldt voor inlichtingen- en veiligheidsdiensten zeker de vaststelling dat onbekend ook onbemind is, maar de gevolgen hiervan zijn verreikender dan het louter ontbreken van een 'love affair' tussen de Belgische geheime diensten en de publieke en politieke opinie.

Men dient inderdaad vast te stellen dat, tot voor vrij recent nog, België één van de weinige landen is waar er geen of praktisch geen cultuur van inlichtingenwerk en inlichtingendiensten bestaat. ${ }^{6}$ Daar waar de meeste landen van de Europese

4. Het volstaat te verwijzen naar het feit dat verschillende diensten vrij grondig uitgebouwde websites hebben. Het geheime karakter van een 'geheime' dienst lijkt dus voornamelijk en om evidente redenen betrekking te hebben op de operationele werking ervan.

5. B. Van Geebergen en D. Van Daele, 'Geheime (?) diensten. Over de noodzaak van een ernstig debat over de bijzondere inlichtingenmethoden en de rol van inlichtingen- en veiligheidsdiensten in de opsporing', Orde van de Dag, Kluwer, afl.42, juli 2008.

6. S. Petermann, 'La Belgian Intelligence Studies Association: pour une culture du renseignement en Belgique', in M.Cools, K. Dassen, R. Libert en P. Ponsaers (eds.), De Staatsueiligheid Essays over 175 jaar Veiligheid van de Staat, Politeia, $367-370$. 
Unie en meer in het algemeen landen met een Angelsaksische traditie7 inlichtingenwerk beschouwen als een onmisbaar element in de politieke besluitvorming en in de handhaving van het algemeen belang, lijkt deze benadering totaal afwezig te zijn in ons land,waar het eerder 'de bon ton' is - niet gestoord door enige terrein- of dossierkennis terzake - de inlichtingendiensten af te schilderen als amateuristisch, onbekwaam of als een blunderend korps.

Onafgezien van het feit dat aan deze houding waarschijnlijk ook historische en sociologische redenen ten grondslag liggen, speelt ook de onwetendheid over de bevoegdheden, de middelen en het actieterrein van de inlichtingendiensten hierin een grote rol.

Teneinde misverstanden te vermijden over wat inlichtingen- en veiligheidsdiensten doen en niet doen en met welke middelen is het onontbeerlijk een korte voorstelling te geven van de twee in België bestaande diensten, met name de Veiligheid van de Staat (VSSE), burgerlijke inlichtingen- en veiligheidsdienst en de Algemene Dienst Inlichting en Veiligheid van de Krijgsmacht (ADIV), militaire inlichtingenen veiligheidsdienst. De nadruk hierbij zal liggen op de burgerlijke inlichtingen- en veiligheidsdienst.

Het weze hier ook benadrukt dat, ondanks het feit dat de Veiligheid van de Staat - toen onder de benaming Openbare Veiligheid - reeds bij besluit van I5 oktober I830 werd opgericht, ${ }^{8}$ de organieke wet voor de inlichtingen- en veiligheidsdienst pas dateert van 30 november $1998^{9}$ (hierna W.I.V.).

Niet onbelangrijk lijkt het ook aan te stippen dat alhoewel er nog geen organieke wet was voor de inlichtingendiensten er wel reeds bij wet van I8 juli I99I een regeling tot stand komt betreffende het toezicht op politie-en inlichtingendiensten. ${ }^{\text {Io }}$ Zoals destijds door sommigen onderstreept lijkt het bijzonder onlogisch een regeling van toezicht en controle uit te werken voor een dienst waarvan op dat ogenblik de organisatie en de bevoegdheden nog niet in een wet zijn vastgelegd. ${ }^{\text {II }}$

Hetgeen ons inziens evenwel,meer nog dan het gebrek aan logica, uit deze handelswijze spreekt is de achterdocht ten opzichte van de inlichtingendiensten, die men trouwens ook terugvindt in de besprekingen over de BIM-wetgeving en die ook als een rode draad loopt in de problematiek die het voorwerp uitmaakt van dit preadvies.

7. Het imago van de Britse diensten en het aura waarmee ze bekleed zijn als 'last expression of national identity and sovereignty' is daarvan de perfecte illustratie.

8. R. Libert,'In vogelvlucht De geschiedenis van 175 jaar Veiligheid van de Staat', in M. Cools, K. Dassen, R. Libert en P. Ponsaers (eds.), De Staatsveiligheid Essays over 175 jaar Veiligheid van de Staat, Politeia, 23-47.

9. Wet van 30 november 1998 houdende regeling van de inlichtingen- en veiligheidsdienst B.S., I8 december 1998 .

Io. Wet van I8 juli I99I tot regeling van het toezicht op politie- en inlichtingendiensten, B.S., 26 juli I991. Bij wet van Io juli 2006 werd de titel aangevuld met 'en op het coördinatieorgaan voor de dreigingsanalyse', ingevolge de wet van ro juli 2006 betreffende de analyse van de dreiging, B.S., 20 juli 2006.

II. Wetsontwerp houdende regeling van de inlichtingen- en veiligheidsdiensten, Uiteenzetting van de minister van Landsverdediging, Parl.St.Senaat, I997-I998, I-758/Io, II. 


\subsection{De veiligheid van de staat (VSSE) $)^{12}$}

De Veiligheid van de Staat werd opgericht op 15-16 oktober I830, hetgeen de VSSE meteen tot de oudste inlichtingendienst ter wereld maakt op één uitzondering na het Sancta Officium van het Vaticaan.

De functie van administrateur-generaal van de Openbare Veiligheid, die in I830 samen met vier andere functies van administrateur-generaal werd opgericht, werd in het begin als een tijdelijk ambt beschouwd, niet toegevoegd aan een ministerie, maar niettemin met zeer ruime bevoegdheden,bepaald in een Koninklijk Besluit van 9 januari 1832 . Later kwam zij onder het toezicht van de minister van Binnenlandse Zaken en nog later onder dat van Justitie.

De Grondwet van I83I voorzag nochtans niet in de oprichting van een orgaan dat met de Staatsveiligheid zou worden belast.

De eerste opdracht voor de Openbare Veiligheid had te maken met de consolidering van de jonge Staat die uit de Belgische Revolutie was ontstaan en op het doorgronden en beheersen van het Hollandse gevaar. België was nog te zwak en men makte zich zorgen over de talloze politieke vluchtelingen afkomstig van de revolutionaire bewegingen op het einde van de $19^{\text {de }}$ eeuw. De voornaamste taak van de Veiligheid in de jaren $1830-1840$ bestond dus in het erop toezien dat het orangisme werd ingedijkt alsmede in de controle van de vreemdelingen.

De periode van I840-I870 is die van de consolidatie van de jonge Belgische staat.

De overheid besloot de Openbare Veiligheid te behouden gelet op delicate positie van ons land op internationaal vlak en op het toenemend probleem van de vreemdelingen en de vluchtelingen die door de I $^{\text {de }}$-eeuwse revoluties naar België werden gedreven.

Het opkomend socialisme vormde op dat ogenblik het doelwit van de Openbare Veiligheid ${ }^{13}$ en de aandacht van onze veiligheidsdienst werd toegespitst op de sociale onrust die overal te lande de kop opstak.

De periode van I870-I89o zag een internationalisering van de problemen: het begin van de Internationale, de Parijse Commune. Na de oprichting van de Belgische Arbeiderspartij en de invoering van het meervoudig stemrecht ging de belangstelling van de Openbare Veiligheid uit naar de anarchistische groepen.

Nadat in I886 het leger de sociale oproer bloedig had onderdrukt kwam er een breuk binnen de Belgische Werkliedenpartij tengevolge van de afscheiding van de socialisten in de Borinage en in I887 en I888 deden zich verscheidene wilde en gewelddadige stakingen voor.

Het parketen de Ministervan Justitie vermoedden het bestaan van een socialistischrepublikeinse samenzwering tegen de veiligheid van de staat. Het daaropvolgend

\footnotetext{
I2. X. Rousseaux en D. Somer, 'Pour une histoire de la Sûreté de l'Etat en Belgique',in M. Cools, K. Dassen, R. Libert en P. Ponsaers (eds.), De Staatsveiligheid Essays over 175 jaar Veiligheid van de Staat, Politeia, 49-74 zie R. Libert,o.c.,23-47 .

I3. In I848 werd Karl Marx door de Veiligheid uitgewezen.
} 
proces voor het Hof van Assisen bracht aan het licht dat de onruststokers van de sociale onlusten informanten waren in dienst van de administrateur-generaal van de Openbare Veiligheid.

De gevolgen bleven niet uit. De administrateur-generaal werd in disponibiliteit gesteld, de agenten in dienst van de Openbare Veiligheid werden ontslagen, het budget werd drastisch verminderd, de rechtstreeks toegekende bevoegdheden van de administrateur-generaal werden in I8go teruggeschroefd en uiteindelijk werd de functie zelf afgeschaft en vervangen door die van directeur-generaal, terwijl de minister zelf de bevoegdheden van de administrateur uitoefende.

De minister droeg evenwel vrij vlug bij delegatie alle bevoegdheden opnieuw over aan de directeur-generaal, zodat in de praktijk de toestand niet erg wijzigde.

De jaren I89o tot I9I4 worden gekenmerkt door de internationalisering van de bewegingen van anarchisten en nihilisten, hetgeen tot gevolg heeft dat de westerse mogendheden hun wetgeving verstrengen, hun internationale contacten uitbreiden en de effectieven van hun politiediensten verhogen. Zo onderhoudt de Openbare Veiligheid bijvoorbeeld contacten met de beruchte tsaristische politieke politie Okhrana.

België blijft zeer behoedzaam op het vlak van het inlichtingenwerk, maar men stelt toch een institutionalisering vast van de contacten van politie, parketten en Openbare Veiligheid, dit onder andere ten gevolge van het feit dat de Openbare Veiligheid slechts over een beperkt personeelskader beschikt.

Tijdens deze periode wordt de Openbare Veiligheid door alle regeringen zonder uitzondering beschouwd als een centraliserend organisme voor de studie van de buitenparlementaire beweging van socialisten en de Belgische en buitenlandse anarchisten.

Over de activiteiten van de Openbare Veiligheid tijdens de Eerste Wereldoorlog is weinig geweten. Belangrijk te vermelden is de oprichting op II oktober I9I6, in volle oorlog, van een militaire veiligheidsdienst.

In het interbellum tussen 1918 en 1940 zijn het de communistische beweging, alsook de nationalistische stromingen waarvoor de Openbare Veiligheid vooral belangstelling heeft

Bij Koninklijk Besluit van 25 november 1925 wordt de functie van administrateurgeneraal van de Openbare Veiligheid opnieuw ingevoerd, met de titel van administrateur-directeur-generaal. Op dat ogenblik was de Openbare Veiligheid als derde algemene directie van het ministerie van Justitie belast met de algemene politie, de paspoorten en visa, de vreemdelingenpolitie, de school voor criminologie en wetenschappelijke politie, de gerechtelijke techniek en laboratoria en de gerechtelijke identificatiedienst en fotografie.

Op 23 februari 1929 publiceert het Utrechts Dagblad de tekstvan een geheim FransBelgisch akkoord volgens hetwelk ingeval van nieuwe oorlog met het Duitse Rijk, Belgische troepen zouden oprukken over Nederlands grondgebied. Het akkoord dat 
later zou bekend geraken als de 'Utrechtse documenten'I4 bleek een vervalsing te zijn die door een zekere Heine in de handen was gespeeld van de Vlaams-nationalist Ward Hermans. Heine bekende de vervalsing te hebben gepleegd in samenwerking met enkele ambtenaren van de Belgische militaire veiligheidsdienst. ${ }^{15}$ Het schandaal is enorm en de gevolgen laten niet op zich wachten. Eerste minister Jaspar beloofde de militaire veiligheidsdienst los te maken van de gemengde legerstaf en onder te brengen bij andere veiligheidsdiensten.

Bij Koninklijk Besluit van I6 maart I929 wordt de militaire veiligheidsdienst overgeheveld naar de Openbare Veiligheid en gelijktijdig wordt in de schoot van deze Openbare Veiligheid een eerste directie Veiligheid van de Staat opgericht. Een tweede directie wordt belast met de vreemdelingenpolitie en een derde met de school voor criminologie en wetenschappelijke politie. Het personeel en de bevoegdheden van de militaire inlichtingendienst,met name contraspionage, gaan naar de Veiligheid van de Staat. ${ }^{16}$ Opvallend is dat de algemene politie - een bevoegdheid van de Openbare Veiligheid sedert I830 - vanaf I929 niet meer voorkomt in de bevoegdheden van deze administratie.

Ander zeer belangrijk element dat we reeds vanaf 1830 kunnen vaststellen is het bijzonder groot belang dat wordt gehecht aan de vreemdelingenpolitie (later de dienst vreemdelingenzaken). ${ }^{17}$

Bij het naderen van de tweede wereldoorlog wordt de Veiligheid van de Staat samen met een aantal diensten van de tweede directie van de Openbare Veiligheid van het ministerie van Justitie naar het ministerie van Landsverdediging overgebracht, alwaar een Bestuur van de Veiligheid van de Staat wordt opgericht onder de leiding van een administrateur. ${ }^{18}$

De Veiligheid van de Staat wordt gedurende de bezetting ontmanteld, maar de regering in ballingschap te Londen richt in oktober-november 1940 de Veiligheid van de Staat opnieuw op.

Door het uitbreken van de oorlog krijgt de administrateur-generaal zeer uitgebreide bevoegdheden, zowel op het vlak van de politiediensten ${ }^{19}$ als voor het opsporen van bedreigingen van zowel burgerlijke als militaire veiligheid. De regering in ballingschap geeft aan de Veiligheid van de Staat de opdracht clandestiene acties uit

I4. G. Provoost, 'Het Frans-Belgisch militair accoord van I 920 en de zaak der Utrechtse documenten in I929', Res Publica no 2, I969, 327-349.

I5. Het is niet zeer duidelijk welke de juiste rol van de militaire veiligheidsdienst was: de documenten doorspelen aan de Duitsers, voor wie Heine nog had gewerkt en aldus aan desinformatie doen of een slag toebrengen aan de Vlaamse Frontpartij in het vooruitzicht van de verkiezingen van 1929 ?

I6. Ze zullen in 1937 opnieuw overgaan naar de Algemene Legerstaf.

17. Tot 3i december 1993 zullen de Veiligheid van de Staat en de Dienst Vreemdelingenzaken samen het Bestuur van de Openbare Veiligheid uitmaken. De school voor criminologie is intussen reeds een aparte instelling geworden en wordt nadien bij de oprichting van de eenheidspolitie afgeschaft.

I8. K.B. 8 maart 1940 tot inrichting van het Bestuur van den Veiligheid van den Staat, B.S., Io maart I940. Na enkele maanden zal de overstap naar Justitie opnieuw worden gemaakt.

I9. De leden van de dienst worden inderdaad voor de duur van de oorlog bekleed met bevoegdheden van gerechtelijke politie. 
te voeren in bezet gebied alsmede een inlichtingendienst te organiseren, ontsnappingslijnen op het continent op te zetten alsmede sabotage- en geheime propagandanetten, terwijl de dienst ook belast is met het voorbereiden van de naoorlogse repressie en de epuratie.

De Veiligheid van de Staat zal van ongemeen belang zijn als schakel tussen bezet België aan de ene kant, de Belgische regering te Londen en de geallieerde legerleiding aan de andere kant. ${ }^{20} \mathrm{Ze}$ speelt een determinerende rol bij de verschillende soorten van verzet in bezet België, met name in de koerierdiensten, de ontsnappingslijnen, de inlichtingendiensten en er zal ook een omgekeerde beweging, vanuit België naar Londen ${ }^{21}$ tot stand komen.

De periode van de bezetting en van de Veiligheid van de Staat in Londen was op meerdere vlakken cruciaal in de geschiedenis van de dienst: er werden op dat ogenblik belangrijke rekruteringen van personeel gedaan, de bevoegdheid van contraspionage werd veel belangrijker en de basis voor diepgaande contacten met buitenlandse diensten,in de eerste plaats met de Britse SIS, werd op dat ogenblik gelegd.

Bij het einde van de Tweede Wereldoorlog wordt de Veiligheid van de Staat belast met de strijd tegen het incivisme en de epuratie, terwijl ze ook haar aandacht toespitst op de activiteiten van de communisten. Gedurende deze periode wordt de dienst opnieuw ondergebracht bij het Ministerie van Landsverdediging, dit tot op het ogenblik dat het leger opnieuw op vredesvoet wordt geplaatst.

In juli I946 komt de dienst terug bij het ministerie van Justitie en op dat ogenblik wordt ook de splitsing doorgevoerd van de bevoegdheden tussen de Veiligheid van de Staat en de diensten van de Algemene Legerstaf die met de sedert 1943 opgerichte SDRA bevoegd zal zijn voor de militaire aangelegenheden (algemene inlichtingen op militair gebied, militaire contra-informatie). Langzamerhand vervallen de bevoegdheden toegekend tijdens de oorlogsjaren, met name de taken van gerechtelijke politie bij het auditoraat-generaal in verband met de misdrijven tegen de veiligheid van de staat (1947), de bevoegdheid van de beteugeling van oorlogsmisdaden (1949) en deze met betrekking tot de gewone bevoegdheden van de krijgsraden te velde (I95I).

De Veiligheid van de Staat zal ook opnieuw de Algemene Directie van de Openbare Veiligheid vervoegen en tot 3I december 1993 één van de twee afdelingen vormen van de Openbare Veiligheid samen met de vreemdelingenpolitie (later de dienst vreemdelingenzaken).

De interessesfeer van de Veiligheid van de Staat gaat zich in de volgende jaren toespitsen op uiterst links, gelet op de Koude Oorlog, maar eveneens op uiterst rechts, contraspionage, subversie en meer en meer ook naar terrorisme.

20. Winston Churchill zal in zijn memoires gewag maken van deze samenwerking.

2I. Zo wordt W. Ugeux, leidend lid van het netwerk Zero de directeur-generaal van de SDRA in Londen, terwijl ook auditeur-generaal Ganshof van der Meersch naar Londen zal vluchten en er de Hoog-Commissaris voor de Veiligheid van de Staat zal worden. 
Belangrijk is het daarbij te onderstrepen dat er nog steeds geen wettelijk kader voorhanden is en dat alles geregeld wordt via Koninklijke besluiten, Ministeriële besluiten of dienstnota's.

In I964 publiceert de toenmalige administrateur-generaal Caeymaex een nota over de werking en zending van de openbare Veiligheid ${ }^{22}$ waarin hij de openbare veiligheid definieert door aan het concept een zeer ruime inhoud te geven, met name alles wat raakt aan de veiligheid van de gevestigde machten en de bevolking.

De bevoegdheidsdomeinen worden ook afgebakend:

- de strijd tegen de binnenlandse subversie, zowel individuele als georganiseerde, van Belgische of buitenlandse oorsprong, van sociale, culturele, administratieve, economische, politieke of strafrecherlijke aard;

- het bestrijden van de buitenlandse subversie door tegensubversie, te weten contraspionage, contrasabotage, en tegeninmenging;

- de bescherming van personaliteiten, leden van de regering, hoge diplomaten en leden van de koninklijke familie;

- de vreemdelingenpolitie op politiek vlak;

- meer algemeen het informeren spontaan of op aanvraag van regering en bevoegde overheden.

Naast het toenemend belang voor contraspionage, voornamelijk onder de invloed van de CIA en gelet op de NAVO vestiging in België, zal er ook meer en meer aandacht uitgaan naar extreemrechtse bewegingen, naar terrorisme en naar groot banditisme. Ons land wordt inderdaad in de jaren 80 geteisterd door zowel terreuraanslagen (aanslag op de synagoge te Brussel in I982, inheems terrorisme van de CCC vanaf I984) als grootschalig banditisme met de aanslagen van de bende van Nijvel.

De jaren 80 zijn ook jaren waarin een aantal ophefmakende affaires aan het licht komen (zaak Graindorge, Westland New Post, de Bonvoisin, Gladio) met als gevolg dat de werking van de politie- en inlichtingendiensten meermaals in vraag wordt gesteld en er in die jaren dan ook niet minder dan drie parlementaire onderzoekscommissies zullen worden opgericht over de werking van deze diensten. ${ }^{23}$ Sommigen gingen toen zo ver dat zij het bestaan zelf van de Belgische inlichtingendiensten ter discussie stelden.

Na de parlementsverkiezingen van 1987 wordt in het regeerakkoord voorzien in de invoering van een parlementair toezicht op de politie-en inlichtingendiensten en wordt een gemengde commissie in het leven geroepen.

In juni I99o kwam er een antwoord met het Pinksterplan, een door de regering goedgekeurd politiek programma inzake ordehandhaving, veiligheid en beteugeling van misdrijven. Het vloeide voort uit de resultaten van de werkzaamheden in de Onderzoekscommissie over de manier waarop de strijd tegen de criminaliteit en het terrorisme is gevoerd. Dit plan behelsde onder meer een reorganisatie van de

22. L. Caeymaex, 'Machten,zendingen en methoden van de Veiligheid van de Staat', De Politieofficier, I964, nr.9, 30-4I.

23. Commissie Wijninckx, Heizelcommissie en commissie Bourgeois. 
Veiligheid van de Staat en de indiening van een ontwerp van wet tot omschrijving van haar opdrachten.

De wet van 18 juli $199 \mathrm{I}^{24}$ tot regeling van het toezicht op de politie- en inlichtingendiensten ${ }^{25}$ komt als eerste tot stand, hetgeen toch wel merkwaardig te noemen valt, aangezien het controleorgaan derhalve bevoegd wordt over een dienst waarvan de eigen bevoegdheden op dat ogenblik nog niet wettelijk zijn vastgelegd.

Pas zeven jaren later zal eindelijk de wet van 30 november $1998^{26}$ tot stand komen die aan de VSSE en aan de ADIV een wettelijk kader geeft, hun opdrachten omschrijft en definieert en de uitoefening ervan regelt.

Deze organieke wet gaat er evenwel van uit dat dwangmiddelen slechts mogen worden gebruikt onder de voorwaarden bepaald door de wet. Meer dan tien jaar na de organieke wet wacht de VSSE nog steeds op een dergelijke wettelijke regeling die haar zou toelaten bijzondere methodes voor het verkrijgen van inlichtingen te kunnen aanwenden, zoals het geval is voor de meeste inlichtingendiensten.

\subsection{De algemene dienst inlichting en veiligheid van de krijgsmacht (ADIV)}

Volledigheidshalve vermelden we hier zeer summier de militaire inlichtingendienst, de ADIV.

Vanaf de onafhankelijkheid tot aan het uitbreken van de Eerste Wereldoorlog is België een land zonder territoriale en militaire ambities, dat voornamelijk begaan is met het behouden en vrijwaren van haar neutraliteit.

Het is pas tijdens de Eerste Wereldoorlog, in I9I5, dat voor de hele duur van de oorlog een 'veiligheidsdienst van het leger' zal worden opgericht, die is samengesteld uit commissarissen en inspecteurs die bij het leger de bevoegdheid uitoefenden van officieren van de gerechtelijke politie, hulpofficier van de procureur des Konings. Een jaar later wordt hij door een 'militaire veiligheidsdienst' vervangen, die in IgI9 wordt ontbonden bij een besluit tot oprichting van een militair veiligheidsorgaan bij het bezettingsleger.

In I920 wordt bij het ministerie van Landsverdediging een dienst in het leven geroepen die belast is met de taken van contraspionage in al haar vormen en van toezicht op subversieve groepen binnen het leger.

In 1929 breekt echter het schandaal van de vervalste Utrechtse documenten uit, met de gekende gevolgen: bij Koninklijk Besluit van I6 maart I929 wordt de militaire veiligheidsdienst overgeheveld naar de Openbare Veiligheid en gelijktijdig wordt in de schoot van deze Openbare Veiligheid een eerste directie Veiligheid van de Staat opgericht.

Het personeel en de bevoegdheden van de militaire inlichtingendienst, met name de contra-spionage gaan naar de Veiligheid van de Staat.

24. J.-Cl. Delepière, 'Le Comité permanent de contrôle des services de renseignement', in M. Cools, K. Dassen, R. Libert en P. Ponsaers (eds.), De Staatsveiligheid Essays over 175 jaar Veiligheid van de Staat, Politeia, 225-240.

25. En later, bij wet van Io juli 2006 , uitgebreid tot het OCAD

26. Wet van 30 november 1998 houdende regeling van de inlichtingen -en veiligheidsdienst, B.S., I8 december 1998 . 
Vanaf 1937 zal er in de schoot van de Generale Staf opnieuw een dienst worden opgericht die de bevoegdheden van de beteugeling van spionage op zich neemt.

Bij het uitbreken van de tweede wereldoorlog en de mobilisatie van het leger wordt bij het ministerie van Landsverdediging een 'Directie Veiligheid van de Staat' opgericht en de Veiligheid van de Staat wordt ernaar overgeheveld. Een paar maanden later, in november I940, zal deze directie, die in Londen gevestigd is, bij Justitie worden ondergebracht alvorens in januari 1945 naar Landsverdediging terug te keren.

In I947 worden bij een besluit van de Regent de militaire inlichtingen, de militaire contraspionage en de verwerking van de rapporten van de militaire attachés en de Belgische officieren in het buitenland aan de staf toevertrouwd. Eind I963 wordt in een koninklijk besluit de algemene structuur van het ministerie van Landsverdediging en van de krijgsmacht vastgesteld en krijgt de stafchef daarbij de verantwoordelijkheid voor de opsporing, de verwerking en de verspreiding van de inlichtingen, alsook voor de toepassing van de regels betreffende de militaire veiligheid en de contraspionage.

Een jaar later wordt de Algemene Dienst inlichting en veiligheid, ADIV, geherstructureerd en aan de staf toegevoegd. De chef van ADIV is belast met de militaire en industriële veiligheid en met de betrekkingen met de andere departementen op het gebied van de inlichtingen, de veiligheid en de codering.

De opdrachten van ADIV worden omschreven in een koninklijk besluit dat in december 1989 werd getekend en in maart 1992, in juni 1995 en in juli 1996 werd gewijzigd, totdat de militaire inlichtingendienst, bij dezelfde wet van 30 november I998, eindelijk zijn bevoegdheden en opdrachten wettelijk ziet geregeld worden.

Het is bijzonder belangrijk aan te stippen in het kader van de uiteenzetting die zal volgen, dat de wet van 30 november 1998 in artikel 2 zeer duidelijk heeft bepaald dat de Veiligheid van de Staat en de ADIV de twee inlichtingen- en veiligheidsdiensten van het Koninkrijk zijn.

Dit betekent aldus dat andere diensten, het weze gerechtelijke, politionele of andere deze hoedanigheid derhalve niet bezitten, zodanig dat, alleszins in principe, bevoegdheidsconflicten onbestaande zouden moeten zijn.

\section{Opdrachten en bevoegdheden van de veiligheid van de staat}

\section{I Algemene opmerkingen}

Zoals reeds hierboven aangestipt is de Veiligheid van de Staat de enige burgerlijke inlichtingen- en veiligheidsdienst in België.

Hierbij dienen een aantal kenmerken te worden onderstreept die eigen zijn aan de dienst.

Allereerst gaat het om een defensieve dienst, dit in tegenstelling tot diensten die operationele bevoegdheden hebben buiten de grenzen van hun nationaal territo- 
rium. ${ }^{27}$ De Veiligheid van de Staat heeft dus niet de bevoegdheid om te opereren buiten het territorium van België en beschikt derhalve ook niet over in het buitenland actieve inlichtingsofficieren.

Het gaat hier uiteraard om een politiek geïnspireerde keuze waarover het, in het kader van deze bijdrage, niet past uit te weiden, temeer dat dergelijke keuzes kunnen veranderen onder de druk van gebeurtenissen en omstandigheden.

Wel dient de vraag gesteld te worden of een inlichtingendienst in de $2 \mathrm{I}^{\text {ste }}$ eeuw, met een internationalisering van de bedreigingen, überhaupt nog zuiver defensief kan blijven. Een tussenweg lijkt aanneembaar, in de mate dat, zonder een operationele offensieve dienst te worden, het mogelijk zou moeten zijn om op bepaalde strategische plaatsen, afhankelijk van de actualiteit, de interessesferen van de dienst en de geografische situatie liaisonofficieren te installeren of rondreizende officieren te hebben die, ter gelegener tijd een bepaalde regio kunnen bestrijken.

Zoals reeds is gebleken is de Veiligheid van de Staat de enige burgerlijke inlichtingen- en veiligheidsdienst, terwijl de ADIV de militaire inlichtingendienst is.

Wanneer men de opdrachten van de twee diensten vergelijkt, ziet men dat ze mekaar op bepaalde punten overlappen, maar het al dan niet militaire karakter van de bedreiging en de betrokken personen - militairen of burgers - bepaalt het onderscheid.

De beide diensten werken evenwel zeer nauw samen en hebben ten dien einde dan ook een protocolakkoord gesloten waarbij zij over welbepaalde thema's op geregelde tijdstippen in gezamenlijke platforms inlichtingen uitwisselen.

Daarenboven dient ook gewezen te worden op het feit dat de ADIV wanneer het de bescherming betreft van de opdrachten van de strijdkrachten of Belgische onderdanen in het buitenland betreft, in tegenstelling tot de Veiligheid van de Staat, wel een bevoegdheid heeft die de landsgrenzen overtreft.

Tenslotte dient ook onderstreept te worden dat de Veiligheid van de Staat een zuivere inlichtingen- en veiligheidsdienst is, waarmee we bedoelen dat de dienst geen enkele gerechtelijke of politionele bevoegdheid heeft, ${ }^{28}$ in tegenstelling tot sommige andere diensten die de beide bevoegdheden hebben in meer of mindere mate. ${ }^{29}$

Dit element is van bijzonder groot belang voor het thema van dit preadvies omdat het duidelijk maakt dat de inlichtingendiensten en de politie- en gerechtelijke diensten een andere finaliteit hebben, hetgeen meteen ook uitlegt dat er moet gezocht worden naar de meest aangepaste manier om deze eigenheid te waarborgen aan de ene kant, maar aan de andere kant ook een systeem moet tot stand worden gebracht waarin informatie verzameld door de inlichtingendienst en die van belang is voor

27. Sommige diensten hebben de beide bevoegdheden (AIVD), terwijl andere dan zowel een binnenlandse als een buitenlandse inlichtingendienst hebben: de USA met de FBI (binnenland) en de CIA (buitenland), het Verenigd Koninkrijk met BSS en SIS, Frankrijk met DCRI en DGSE, Duitsland met BfV en BND).

28. Met uitzondering van de beschermingsofficieren - zie hierna.

29. Zo zijn de Scandinavische diensten in se politiediensten met een inlichtingenbevoegdheid, terwijl bijv. de Franse DCRI ook een bevoegdheid heeft van gerechtelijke politie. 
politioneel en gerechtelijk onderzoek op de meest gepaste manier kan worden aangeleverd.

\subsection{De opdrachten}

De opdrachten van de Veiligheid van de Staat zijn vastgelegd in de artikelen 7 en 8 van de Wet van 30 november 1998.

Het artikel 7 somt de vier opdrachten op, terwijl het artikel 8 meer in detail de gehanteerde begrippen definieert.

De opdrachten zijn de volgende:

- het inwinnen, analyseren en verwerken van inlichtingen die betrekking hebben op elke activiteit die de inwendige veiligheid van de staat en het voortbestaan van de democratische en grondwettelijke orde, de uitwendige veiligheid van de staat en de internationale betrekkingen, het wetenschappelijk of economisch potentieel of elk ander fundamenteel belang van het land bedreigt of zou kunnen bedreigen;

- het uitvoeren van veiligheidsonderzoeken;

- het uitvoeren van de opdrachten tot bescherming van personen die haar worden toevertrouwd door de minister van Binnenlandse Zaken;

- het uitvoeren van alle andere opdrachten die haar door of krachtens de wet worden toevertrouwd.

De eerste opdracht is de klassieke inlichtingenopdracht, terwijl de drie anderen, die we eerst kort zullen bespreken, meer specifieke bevoegdheden betreffen.

De veiligheidsonderzoeken worden door de Veiligheid van de Staat uitgevoerd op verzoek van de Nationale Veiligheidsoverheid (NVO) die uiteindelijk de veiligheidsmachtigingen aflevert ${ }^{30}$ en zijn wettelijk geregeld in de Wet van II december 1998 betreffende de classificatie en de veiligheidsmachtigingen, veiligheidsattesten en veiligheidsadviezen (hierna Classificatiewet).

Het gaat om doorlichtingen van natuurlijke en rechtspersonen die in aanraking komen met geclassificeerde informatie en derhalve over een aangepaste veiligheidsmachtiging dienen te beschikken. ${ }^{3 \mathrm{I}}$

De opdracht tot bescherming van personen geschiedt op vraag van de minister van Binnenlandse Zaken en heeft betrekking op buitenlandse staatshoofden en hun familieleden, buitenlandse regeringsleiders en hun familieleden, Belgische en buitenlandse regeringsleden en bepaalde belangrijke personen die het voorwerp uitmaken van bedreigingen.

30. Behalve voor het eigen personeel van de inlichtingendiensten waarvoor de hoofden van de dienst zelf deze bevoegdheid hebben.

3I. Naast personeel van de inlichtingendiensten kan dit betrekking hebben op leden van politiediensten, bepaalde bewakingsfirma's, privédetectives e.d. 
Het is niet gebruikelijk dat een inlichtingen- en veiligheidsdienst een protectiebevoegdheid heeft en meestal wordt die dan ook aan een gespecialiseerd korps toevertrouwd.

Binnen de Veiligheid van de Staat wordt deze opdracht uitgevoerd door een afdeling van de operationele diensten, dus specifiek aangeduide beschermingsofficieren, die gedurende deze aanduiding de enigen zijn om deze opdracht te mogen uitvoeren,met uitsluiting van elke andere opdracht.

Gelet op de impact die dit heeft op de werking van de dienst, werd sedert 2008 gestart met de aanwerving binnen de Veiligheid van de Staat van protectieassistenten, die dus een specifiek korps vormen dat enkel en alleen belast is met deze beschermingsopdracht,waardoor het overgrote deel van de leden van de buitendiensten kunnen worden ingezet voor hetgeen hun core-business is, namelijk de inlichtingenverzameling.

Enkel in de uitoefening van deze beschermingsopdracht beschikken de beschermingsofficieren over beperkte en specifieke politionele bevoegdheid die hen moet toelaten om tussen te komen wanneer het leven of de fysische integriteit van de te beschermen persoon in gevaar komt. Zo mogen zij overgaan tot identiteitscontrole, veiligheidsfouilleringen, inbeslagnemingen en administratieve vrijheidsbenemingen uitvoeren.

Tot slot kunnen er ook specifieke opdrachten door of krachtens de wet worden toevertrouwd aan de Veiligheid van de Staat. Deze categorie werd ingevoerd om te vermijden dat de wet constant zou moeten worden aangepast. ${ }^{32}$ Door de vereiste van een wet te stellen wordt aldus ook voldaan aan artikel 8, lid 2 EVRM. 33 Aldus wordt de dienst geraadpleegd bij aanvragen tot wapenvergunning door personen die niet in België woonachtig zijn.

De belangrijkste opdracht is uiteraard de inlichtingenopdracht.

Zoals reeds hierboven gesteld betreft het hier het inwinnen, analyseren en verwerken van inlichtingen die betrekking hebben op elke activiteit die de inwendige veiligheid van de staat en het voortbestaan van de democratische en grondwettelijke orde, de uitwendige veiligheid van de staat en de internationale betrekkingen, het wetenschappelijk of economisch potentieel of elk ander fundamenteel belang van het land bedreigt of zou kunnen bedreigen.

Deze omschrijving verdient enige toelichting met betrekking tot de gehanteerde begrippen aangezien ze zowel de structuur van de dienst behelst als de verschillende domeinen waarop de Veiligheid van de Staat actief is.

Eerst en vooral is het belangrijk te onderstrepen dat de Veiligheid van de Staat belast is met het inwinnen van inlichtingen - hetgeen in hoofdzaak de opdracht is van de operationele diensten (de buitendiensten) - die dan worden geanalyseerd - hetgeen de taak is in hoofdzaak van de analysediensten (de binnendiensten) - om

32. Parl. St., Kamer, I995-I996, nr. 638/1,3.

33. F. Goossens, 'De Veiligheid van de Staat:haar wettelijk kader' in M. Cools, K. Dassen, R. Libert en P. Ponsaers (eds.), De Staatsveiligheid Essays over 175 jaar Veiligheid van de Staat, Politeia, 208. 
tenslotte na verwerking te worden meegedeeld aan de verschillende belanghebbenden (de stakeholders).

De dienst bestaat derhalve uit een kader van inspecteurs en commissarissen die de operationele diensten uitmaken en uit een kader van analysten en assistent-analysten die de analysediensten vormen, alsmede uit de algemene diensten (administratieve diensten, juristen, vertalers, boekhouders enz.).

Ook belangrijk is dat de Veiligheid van de Staat in algemene regel enkel geanalyseerde informatie doorgeeft en geen raw intelligence.

Tenslotte dient erop te worden gewezen dat, net door de noodzaak aan analyse en verwerking, er een wezenlijk verschil bestaat tussen een loutere informatie en een geanalyseerde en verwerkte inlichting. Het is pas door het toetsen van een informatie aan andere informaties en door de verificatie ervan aan verschillende bronnen, dat een info kan worden omgezet in een inlichting in de betekenis die inlichtingendiensten daaraan geven.

In deze zin moet dan ook de totstandkoming van een BIM-wetgeving worden toegejuicht, omdat ze de Belgische inlichtingendiensten de mogelijkheid zal geven onder bepaalde strikte voorwaarden over meer middelen te beschikken die hen moeten toelaten hun opdrachten uit te voeren en derhalve de aangeleverde inlichtingen, alsmede de analyse en de verificatie ervan, te verfijnen.

De inwendige veiligheid van de staat en het voortbestaan van de democratische en grondwettelijke orde hebben betrekking op de veiligheid van de instellingen van de staat en de vrijwaring van de continuïteit van de werking van de rechtsstaat, de democratische instellingen ervan en de elementaire principes die er eigen aan zijn, alsook de fundamentele vrijheden en de mensenrechten. Ook de veiligheid van personen en de vrijwaring van goederen worden hierdoor geviseerd.

De inwendige veiligheid van de staat en de internationale betrekkingen refereert naar de vrijwaring van de onschendbaarheid van het nationaal grondgebied, de soevereiniteit en de onafhankelijkheid van de staat, de relaties met andere landen of met internationale of supranationale instellingen.

De vrijwaring van het wetenschappelijk en economisch potentieel werd eveneens opgenomen in de kaderwet van 30 november 1998, maar werd pas ingevuld en gedefinieerd door het Ministerieel Comité voor Inlichtingen en Veiligheid in 2007 als het vrijwaren van de essentiële elementen die het voortbestaan en de optimale ontwikkeling van het socio-economisch model mogelijk maken, te weten:

- de economische soevereiniteit van de Staat;

- de veiligheid van de kritische infrastructuur;

- de producten van wetenschappelijk onderzoek en onderzoek en ontwikkeling;

- een vrije, veilige en eerlijke omgeving voor de economische actoren.

De vraag die dus nog openblijft is welke de activiteiten zijn die als een mogelijke bedreiging worden ervaren en die dus moeten worden in kaart gebracht. Artikel 8 van de wet omschrijft ze als elke individuele of collectieve activiteit, ontplooid in het land of vanuit het buitenland die verband kan houden met spionage, inmenging, terrorisme, extremisme, proliferatie, schadelijke sektarische organisaties en criminele 
organisaties, daarbij inbegrepen de verspreiding van propaganda, de aanmoediging of de rechtstreekse of onrechtsreekse steun, onder meer door het verstrekken van financiële, technische of logistieke middelen, het verstrekken van inlichtingen over mogelijke doelwitten, de ontwikkeling van structuren en van actiecapaciteiten en de verwezenlijking van de nagestreefde doeleinden.

Het artikel definieert verder wat juist onder deze begrippen dient te worden verstaan, maar het essentiële is dat de opsomming limitatief is en dat gans de inlichtingenopdracht vanuit deze bedreigingen dient te worden benaderd.

Dit betekent bijvoorbeeld dat ook de vrijwaring van het wetenschappelijk en economisch potentieel gebonden is aan het bestaan van één of meer van de hiervoor vermelde bedreigingen.

Het wetenschappelijk en economisch potentieel kan inderdaad ook bedreigd worden door andere factoren dan diegene opgesomd hierboven, maar zij behoren niet tot de bevoegdheid van de Veiligheid van de Staat. Een economische evolutie of crisis is zeer zeker van aard het wetenschappelijk en economisch potentieel in gevaar te brengen, maar het is een bedreiging die niet in de sfeer van de Veiligheid van de Staat ligt.

Het is dus belangrijk dat de juiste draagwijdte van deze opdracht van de Veiligheid van de Staat duidelijk wordt begrepen en bijvoorbeeld niet wordt vergeleken of verward met de bevoegdheden die diensten van andere Westerse landen ter zake bezitten. In sommige landen inderdaad 34 hebben de inlichtingendiensten op dit vlak zeer verregaande bevoegdheden, die samenhangen met deze van de regering, die kan tussenkomen in de markteconomie en de afsluiting van bepaalde contracten kan beletten omdat ze indruisen tegen 's lands economisch belang.

\subsection{De bevoegdheden}

Om deze opdrachten uit te voeren heeft de Veiligheid van de Staat uiteraard bevoegdheden, dwangmiddelen nodig. Ook hier dient te worden vastgesteld dat het wantrouwen ten opzichte van de inlichtingendiensten zich heeft geuit in een totnogtoe zeer beperkte toekenning van middelen en het ontbreken van een specifieke wetgeving inzake bijzondere inlichtingenmethoden, naar analogie met deze waarover de politiediensten reeds beschikken sedert 2003.

De lege lata wordt in artikel I2 van de wet van 30 november 1998 een overkoepelend beginsel gehanteerd volgens hetwelk de inlichtingen- en veiligheidsdiensten slechts dwangmiddelen mogen gebruiken onder de voorwaarden die door de wet worden bepaald.

In de voorbereidende werken wordt door de regering uitdrukkelijk verwezen naar het legaliliteitsprincipe, waarbij de inlichtingen- en veiligheidsdiensten over geen ander dwangmiddel beschikken dan deze bepaald bij de wet. 35 Met andere woorden kan de Staatsveiligheid of de ADIV geen methode toepassen, zolang deze niet in de wet is ingeschreven.

34. We denken hier bijvoorbeeld aan Frankrijk.

35. Parl. St. Kamer, I995-I996, nr. 638/I, I3. 
Het artikel I3 W.I.V. stelt uitdrukkelijk dat de inlichtingen- en veiligheidsdiensten in het kader van hun opdrachten inlichtingen en persoonsgegevens die nuttig kunnen zijn om hun opdrachten te vervullen, kunnen opsporen, verzamelen, ontvangen en verwerken. Bovendien laat dit artikel toe een documentatie bij te houden van de gebeurtenissen, de groeperingen en de personen die een belang vertonen voor de uitoefening van hun opdrachten. De inlichtingen die bijgehouden worden, moeten in verband staan met de doeleinden van het gegevensbestand en beperkt blijven tot de daaruit voortvloeiende vereisten.

De artikelen I4 tot en met I8 W.I.V. bepalen op welke wijzen de inlichtingendiensten op dit ogenblik gegevens kunnen verzamelen. Een eerste mogelijkheid tot het verkrijgen van gegevens is deze waarbij de gerechtelijke overheden, de ambtenaren en de agenten van de openbare diensten uit eigen beweging aan de betrokken inlichtingen- en veiligheidsdienst inlichtingen meedelen die nuttig zijn voor de uitvoering van zijn opdrachten. Echter moet bij het overdragen van gegevens, naast hetgeen bepaald is in de wet, tevens rekening gehouden worden met eventuele akkoorden of regels die door de verantwoordelijke overheid aan de overdragers van inlichtingen worden opgelegd. In gelijkaardige omstandigheden kunnen de gerechtelijke overheden, de ambtenaren en agenten van de openbare diensten door de inlichtingendienst verzocht worden inlichtingen mede te delen die nuttig zijn voor de uitvoering van zijn opdrachten. Deze verschillende instanties kunnen de mededeling van de gevraagde informatie weigeren, mits ze binnen de maand schriftelijk de redenen daartoe opgeven (art. I4 W.I.V.).

Artikel I5 W.I.V. laat toe dat de inlichtingendienst mededeling vraagt van de gegevens uit het bevolkings- en vreemdelingenregister, of uit het wachtregister van de vreemdelingen.

Het artikel I6 W.I.V. biedt, met verwijzing naar de wet van 8 december 1992 tot bescherming van de persoonlijke levenssfeer ten opzichte van de verwerking van persoonsgegevens, de mogelijkheid om inlichtingen en persoonsgegevens in te winnen bij elke persoon of organisatie die tot de privésector behoort, voor zover die gegevens noodzakelijk zijn voor de uitoefening van hun opdrachten.

Het huidige artikel 17 W.I.V. laat de inlichtingen- en veiligheidsdiensten toe de voor het publiek toegankelijke plaatsen te betreden en, weliswaar met inachtneming van de onschendbaarheid van de woning, hotelinrichtingen en andere logiesverstrekkende inrichtingen te bezoeken.

Ten slotte kunnen de inlichtingendiensten een beroep doen op menselijke bronnen (art. I8 W.I.V.). De bezorgdheid om naar zijn informanten - maar tevens ten aanzien van de buitenlandse inlichtingendiensten - geloofwaardig over te komen, werd opgenomen in het artikel I8 W.I.V., waarbij de diensten de opdracht gegeven wordt om te waken over de veiligheid van de gegevens die op de menselijke bronnen betrekking hebben en over de inlichtingen die ze mededelen.

Zoals kan worden vastgesteld, zijn de middelen waarover de inlichtingendiensten beschikken in België bijzonder beperkend opgevat, hetgeen niet enkel tot gevolg heeft dat de diensten niet voldoende gewapend zijn om de bedreigingen doeltref- 
fend op te sporen, maar hen ook zeer afhankelijk maakt van informatie aangeleverd door derde diensten.

Reeds verscheidene jaren wordt benadrukt dat de wettelijke middelen waarover de Veiligheid van de Staat en de ADIV beschikken, ontoereikend zijn om doeltreffend strijd te kunnen leveren tegen het terrorisme, het extremisme, waaronder het radicalisme en de andere ernstige bedreigingen voor de interne en externe veiligheid van de Staat.

In het kader van deze activiteiten en door de toenemende bedreigingen en het systematische gebruik van steeds performantere middelen door de personen en de groeperingen die voor de opdrachten van de diensten belangrijk zijn, onder andere gelet op de vooruitgang van de supergeavanceerde technologie van de communicatiemiddelen en het gebruik van het internet, wordt de doeltreffendheid van de inlichtingendiensten immers verlamd door een gebrek aan geschikte inlichtingenmethoden.

Bijgevolg kunnen de bedoelingen van bepaalde handelingen van deze personen en groeperingen niet altijd aan het licht worden gebracht. Ook al blijft het beroep doen op menselijke bronnen, bijvoorbeeld voor de bewaking van bepaalde groeperingen, zijn volle intrinsieke waarde behouden, toch is het gebruik van deze methode ontegensprekelijk begrensd wegens het fysieke gevaar dat de bron kan lopen. Ook al betekenen de gegevens die door de openbare diensten worden verstrekt, een eerste aanzet van onontbeerlijke gegevens met betrekking tot de persoon die voor de diensten belangrijk is, toch blijven ze in hoofdzaak administratieve gegevens en moeten deze noodzakelijkerwijs worden aangevuld met gegevens die op een discrete wijze operationeel worden verzameld. Enkel door het toekennen van performante middelen, kunnen de inlichtingen- en veiligheidsdiensten in een vroegtijdig stadium van de ontwikkeling van de bedreiging voor de fundamentele belangen van de Staat, hierin begrepen ook de bescherming van de individuele rechten en vrijheden, deze ontwikkelingen opvolgen om indien noodzakelijk een passend optreden mogelijk te maken. Zonder deze bijkomende middelen blijft de inlichtingendienst, geconfronteerd met een steeds grotere uitdaging, compleet machteloos aan de zijlijn staan.

Men mag in dit verband niet vergeten dat de inlichtingendiensten in hun hoedanigheid van steundiensten van het Coördinatieorgaan voor de dreigingsanalyse (OCAD), dit orgaan dienen te bevoorraden met hun analyses, terwijl diensten als de Federale Politie en de Douane die eveneens partners binnen OCAD zijn, over krachtiger onderzoeksmiddelen beschikken om hun opdrachten uit te voeren.

Het pleidooi voor een uitbreiding van de inlichtingenmethoden voor de Veiligheid van de Staat en de ADIV is zeker niet nieuw.

Een belangrijk signaal hiertoe werd reeds gegeven door de Raad van State in zijn advies bij het voorontwerp van de wet van 30 november 1998 , met een oproep aan de regering om een volledige lijst te maken van de technieken waarvan de inlichtingendiensten gebruik konden maken. ${ }^{36}$ De regering volgde toen deze aanbeveling van

36. Parl. St. Kamer I995-I996, nr. 638/I, 30-32. 
de Raad van State niet en vond het niet opportuun een volledige lijst van inlichtingenmethoden op te maken, met uitzondering van de 'veiligheidstap', waarvoor een apart wetsontwerp zou worden opgemaakt.

Een aantal gerechtelijke uitspraken kwamen evenwel de noodzaak aan een afdoende juridische regeling voor de andere methoden voor het verzamelen van gegevens kracht bijzetten.

In het GICM-proces had de verdediging van sommige beklaagden de door de Veiligheid van de Staat verzamelde bewijsmiddelen in vraag gesteld. Men opperde dat de Veiligheid van de Staat tot onwettige telefoonopsporing was overgegaan, terwijl de telefoonnummers in de aanklacht werden verkregen door een beroep te doen op informanten en ook de technieken van schaduwing en observaties werden in vraag gesteld.

Het vonnis ${ }^{37}$ stelde dat:

'qu’à l'évidence, la surveillance d'individus et de groupements potentiellement séditieux découle en ligne directe de ses missions essentiellement définies à l'article 7 , I de la loi du 30 novembre $1998,(. .$.$) qu'il ne fait aucun doute que la Sûreté de l'État$ procède ordinairement à des observations systématiques de lieux, de groupements et de personnes pour rechercher et collecter des données utiles à l'exécution de ses missions; (... ) et qu'elle était habilitée à pratiquer des observations sur pied de l'article $\mathrm{I} 3$ de ladite loi lequel énonce ses moyens généraux d'action (...); (... ) la question subsiste de savoir si ce même article est suffisamment prévisible au sens que donne la Cour de Strasbourg à cette notion; (...) qu'à l'évidence, l'article I3 de la loi du 30 novembre I998 présente une certaine prévisibilité puisqu’à juste titre, l'immense majorité de la population du Royaume ne doute pas un instant que les services de renseignement peuvent procéder et procèdent effectivement à des observations appuyées mais que vu les extensions récentes qu'a connu le principe du respect dû à la vie privée, la définition des moyens dont disposent les services de renseignement demeure particulièrement floue (...) et qu'en l'état de la législation belge prise dans son ensemble, l'énumération "ouverte" de l'article I3 de la loi du 30 novembre 1998 ne répond plus aux exigences de prévisibilité au sens que donne à cette notion la Cour de Strasbourg, laquelle attache certains critères "qualitatifs" à ce concept.'

Deze argumentatie werd evenwel in graad van beroep verworpen.

Het Hof van Beroep te Brussel $3^{8}$ stelde inderdaad dat:

'Cette réglementation ${ }^{39}$ n'édicte pas une prohibition générale de ces méthodes en dehors du cadre judiciaire qu'elle définit. Les missions étrangères à ces objectifs ne sont pas visées par cette loi c'est le cas, en particulier, des services de renseignement

37. Corr. Brussel i6 februari 2006, onuitg.

38. Brussel I9 januari 2007, T. Strafrecht, 2008/4,28I. De voorziening in cassatie tegen dit arrest werd verworpen, Cass.27 juni 2007,R.W.,2008-2009,1634.

39. Bedoeld wordt de wet van 6 januari 2003 op de bijzondere opsporingsmethoden en enige andere onderzoeksmethoden van toepassing op de politiediensten. 
- Sûreté de l'Etat et Service de renseignement de l'armée - qui procèdent quotidiennement à des filatures et entretiennent des réseaux d'indicateurs ${ }^{40}$ (...) Il résulte des considérations qui précèdent que les filatures et les surveillances (...) ont été réalisées conformément aux pouvoirs conférés à ce service par la loi norganique du 30 novembre 1998 ....En outre, les dispositions précitées de cette loi habilitant la Sûreté de l'etat à agir de la sorte respectent les exigences de l'article 8 de la Convention européenne des droits de l'homme, et notamment, les principes de proportionnalité et de finalité. Enfin ces dispositions sont, compte tenu de l'atteinte relative à la vie privée qu'engendrent la filature et les surveillances sur la voie publique, suffisamment explicites et prévisibles.'

Niettemin lijkt een specifieke wetgeving voor inlichtingenvergaring wenselijk, teneinde dergelijke debatten in de toekomst te vermijden en het gebruik van meer intrusieve middelen dan diegene waarover het in dit arrest ging te reglementeren.

Het is ook belangrijk te weten dat het Vast Comité I al vanaf 1994 een wettelijke regeling vroeg van de methoden voor de verzameling van gegevens door de inlichtingendiensten, met name voor de menselijke bronnen, de infiltratie van groeperingen en de observatie. In verschillende latere verslagen stelde zich eveneens de vraag om wetten op te stellen inzake identificatie, opsporing en veiligheidstap, alsook inzake de bijzondere inlichtingenmethoden voor de inlichtingendiensten.

Daar waar de Veiligheid van de Staat momenteel nog steeds - hoe ongelooflijk zoiets ook klinkt in de $2 \mathrm{I}^{\text {ste }}$ eeuw vergeleken met andere diensten en, vooral, vergeleken met de bedreigingen die ze verondersteld is te bestrijden - met pijl en boog werkt, zal de lege ferenda de BIM-wetgeving dit fundamenteel gaan wijzigen.

De op stapel staande wetgeving ${ }^{4 \mathrm{I}}$ kent inderdaad aan de inlichtingendiensten ${ }^{42}$ een zeer brede panoplie van nieuwe middelen toe, ingedeeld in drie onderscheiden categorieën,naargelang de gebruikte methode enerzijds en de intrusie in de privacy die ze met zich meebrengen anderzijds.

De gewone methoden zijn diegene waarover de inlichtingendienst nu al beschikt en die relatief gezien een minimale schending van die privacy met zich meebrengen.

De belangrijkste bepalingen betreffen uiteraard de creatie van twee nieuwe categorieën, met name de specifieke en de uitzonderlijke methoden.

Het gaat hier om middelen die worden gebruikt om de inlichtingen te vergaren en die een steeds groter wordende inbreuk op de privacy met zich meebrengen, hetgeen zich dan ook zal uiten in een toenemend systeem van toezicht en controle op de aanwending ervan.

Voor een goed begrip lijkt het aangewezen deze methoden even op te sommen.

40. Ch. De Valkeneer, 'La loi du 6 janvier 2003 concernant les méthodes particulières de recherche et quelques autres méthodes d'enquête', Actualité du droit pénal, Bruylant, 2005, 257.

4I. Wetsontwerp betreffende de methoden voor het verzamelen van gegevens door de inlichtingenen veiligheidsdiensten, Ontwerp overgezonden door de Senaat, Par.St., Kamer, 52-2128/oor.

42. Veiligheid van de Staat en Algeme Dienst Inlichtingen en Veiligheid. 
De specifieke methoden behelzen:

$\mathrm{I}^{\mathrm{O}}$ de observatie, met behulp van technische middelen, in publieke plaatsen en in private plaatsen die toegankelijk zijn voor het publiek, ofwel de observatie, al dan niet met behulp van technische middelen, van private plaatsen die niet toegankelijk zijn voor het publiek;

$2^{\mathrm{O}}$ de doorzoeking, met behulp van technische middelen, van publieke plaatsen, van private plaatsen die toegankelijk zijn voor het publiek en van de gesloten voorwerpen die zich op deze plaatsen bevinden;

$3^{\circ}$ het kennisnemen van de identificatiegegevens van de afzender of de geadresseerde van post of van de titularis van een postbus;

$4^{\mathrm{o}}$ de maatregelen tot identificatie van de abonnee of de gewoonlijke gebruiker van een dienst van elektronische communicatie of van het gebruikte elektronisch communicatiemiddel;

$5^{\mathrm{o}}$ de maatregelen tot opsporing van de oproepgegevens van elektronische communicatiemiddelen en de lokalisatie van de afkomst of de bestemming van elektronische communicatie.

De uitzonderlijke methoden voor het verzamelen van gegevens zijn:

$\mathrm{I}^{\mathrm{O}}$ de observatie, al dan niet met behulp van technische middelen, in private plaatsen die niet toegankelijk zijn voor het publiek, in woningen of in een door een woning omsloten eigen aanhorigheid in de zin van de artikelen 479, 480 en 48I van het Strafwetboek of een lokaal aangewend voor beroepsdoeleinden of als woonplaats door een advocaat, een arts of een journalist;

$2^{\mathrm{O}}$ de doorzoeking, al dan niet met behulp van technische middelen, van private plaatsen die niet toegankelijk zijn voor het publiek, van woningen of van een door een woning omsloten eigen aanhorigheid in de zin van de artikelen 479, 480 en 48I van het Strafwetboek of van een lokaal aangewend voor beroepsdoeleinden of als woonplaats door een advocaat, een arts of een journalist en van gesloten voorwerpen die zich op deze plaatsen bevinden;

$3^{\mathrm{o}}$ de oprichting of het gebruik van een rechtspersoon ter ondersteuning van operationele activiteiten en het gebruik van agenten van de dienst, onder dekmantel van een fictieve identiteit of hoedanigheid;

$4^{\circ}$ het openmaken en het kennisnemen van de aan een postoperator toevertrouwde post;

$5^{\circ}$ het verzamelen van gegevens betreffende bankrekeningen en bankverrichtingen; 
$6^{\circ}$ het binnendringen in een informaticasysteem, al dan niet met behulp van technische middelen, valse signalen, valse sleutels of valse hoedanigheden;

$7^{\circ}$ het afluisteren, het kennisnemen van en het opnemen van communicaties.

35. Zonder hier in detail te treden kunnen we erop wijzen dat er, naast de reeds bestaande controles waaraan de inlichtingendienst is onderworpen, een uitgebreid systeem op touw wordt gezet van toezicht,controle en in bepaalde gevallen van machtiging. Refererend naar de vaststelling van het EHRM in de zaak Klass t. Duitsland 43 volgens dewelke 'de bewaking een controle in drie stadia kan ondergaan, op het moment dat ze bevolen wordt, terwijl ze uitgevoerd wordt en nadat ermee is opgehouden', werd er geopteerd naar een controle die met de besluitvorming en de uitvoering van de methode gepaard gaat en een controle wanneer de methode beëindigd is.

Er wordt namelijk een Commissie opgericht bestaande uit drie leden die de hoedanigheid hebben van magistraat, 44 die als taak heeft toezicht te houden op de aanwending van de specifieke en uitzonderlijke methoden. De omvang van de taak verschilt evenwel naargelang de gebruikte methode.

Gaat het om een specifieke methode, dan zal de controle enkel a posteriori gebeuren, terwijl voor het inzetten van uitzonderlijke methoden de voorafgaande toestemming van deze commissie vereist is, hetgeen dus een controle a priori veronderstelt.

Daarenboven wordt het Vast Comité van toezicht op de inlichtingen- en veiligheidsdiensten, het Comité I zoals het doorgaans wordt genoemd, in het kader van de BIM-wetgeving, belast met de controle a posteriori van de wettelijkheid van de beslissingen met betrekking tot de specifieke en uitzonderlijke methoden, hieronder begrepen het proportionaliteits- en subsidiariteitsprincipe. Deze controlebevoegdheid doet daarenboven niets af aan de algemene opdracht van het Comité I zoals vastgelegd in de wet van I8 juli I99I tot regeling van het toezicht op de politie- en inlichtingendiensten.

\section{$4 \quad$ Staatsveiligheid en strafvordering}

Zoals hiervoor reeds aangehaald, is de Veiligheid van de Staat een zuivere inlichtingen- en veiligheidsdienst, hetgeen impliceert dat zij geen politie- en gerechtelijke bevoegdheden heeft, wat ook inhoudt dat de Veiligheid van de Staat geen politionele of gerechtelijke finaliteiten heeft.

De Veiligheid van de Staat spoort geen misdrijven en de daders ervan op en het werk van de dienst is ook niet afgestemd op het oplossen van de crisis die ontstaat bij het plegen van een misdrijf. Het onderzoekswerk van politiediensten en gerechtelijke overheden is hoofdzakelijk gericht op het zoeken naar bewijzen in verband met strafbare feiten die gepleegd werden of die zouden kunnen gepleegd worden.

43. EHRM, 6 september 1978 , 5029/7I, Klass t. Duitsland.

44. Een onderzoeksrechter, een zittende magistraat en een lid van het Openbaar Ministerie. 
Voor een inlichtingendienst daarentegen bestaat de taak in het verzamelen van informatie, het verwerken en analyseren ervan teneinde inzicht te verkrijgen in bepaalde constructies en netwerken, het opsporen van fenomenen en structuren en hun eventuele evolutie en verandering, die van aard kunnen zijn een bedreiging te vormen voor de waarden die de Veiligheid van de Staat in stand dient te houden.

Alhoewel de finaliteit van een inlichtingendienst niet politioneel en gerechtelijk is, is het uiteraard mogelijk dat bepaalde verzamelde inlichtingen van belang zijn voor de politie- en gerechtelijke diensten of dat zij aanwijzingen bevatten dat strafbare feiten werden gepleegd. Het is vanzelfsprekend dat in die gevallen de gerechtelijke overheden in kennis dienen te worden gesteld van deze inlichtingen en er bestaan dan ook een aantal wettelijke bepalingen die de overdracht van informatie beheersen.

Anderzijds dient er toch ook op gewezen te worden dat het niet de bedoeling is en dat het ook niet wenselijk zou zijn, dat de politionele en gerechtelijke overheden enerzijds en de inlichtingendiensten anderzijds terechtkomen in een toestand van splendid isolation. Uiteindelijk hebben deze onderscheiden diensten toch een gemene deler,die erin bestaat dat zij allen moeten instaan voor en bijdragen aan het in stand houden van een democratische rechtsorde in de meest brede zin van de term.

Gelet op de verschillen in bevoegdheid en in finaliteit van de politionele en gerechtelijke diensten ten opzichte van de inlichtingendiensten, zou er in principe geen overlapping en concurrentie moeten bestaan. Indien men ervan uitgaat dat politionele en gerechtelijke diensten in hoofdzaak reactief te werk gaan, daar waar inlichtingendiensten een meer prospectieve taak en bevoegdheid hebben, lijkt de afbakening vrij duidelijk en het dient gezegd te worden dat in het verleden de conflicten op dat vlak eerder zeldzaam waren.

Hierin is evenwel een fundamentele wijziging gekomen die, ons inziens, te wijten is aan twee factoren, met name de toenemende interesse van de politiediensten in de proactieve recherche en de terrorismebestrijdingswetgeving.

Het is inderdaad niet steeds even makkelijk het onderscheid te maken tussen de recherche in de proactieve fase die steeds meer en meer veld wint bij de politiediensten en de prospectieve fase die ons inziens thuishoort bij de inlichtingendiensten. Dat politiediensten zich de laatste jaren zeer intensief hebben toegelegd op de proactieve recherche lijkt een trend te zijn die zich ook in de ons omringende landen heeft doorgezet.

De omvang en de impact van de proactieve recherche worden in België evenwel in zeer sterke mate beïnvloed door de omstandigheid dat de politiediensten sedert 2003 beschikken over een wet die hen toelaat bijzondere opsporingsmethoden te gebruiken, ${ }^{45}$ ook in het kader van het opsporingsonderzoek dat zich, overeenkomstig

45. Wet van 6 januari 2003 betreffende de bijzondere opsporingsmethoden en enige andere onderzoeksmethoden, B.S.,I2 mei 2003, hierna BOM-wet genoemd. De wet werd bij arrest van het Grondwettelijk Hof van 2I december 2004, B.S., 6 januari 2005, gedeeltelijk vernietigd en bij wet van 27 december 2005, B.S., 30 december 2005, hierna BOM-reparatiewet genoemd, gedeeltelijk gewijzigd. Voor een overzicht van de totstandkoming van de wet en de ermee gepaard gaande vernietigingen uitgesproken door het Grondwettelijk Hof zie H. Berkmoes en J. Delmulle, Recht op zijn scherpst. De bijzondere opsporingsmethoden en enige andere onderzoeksmethoden, Politeia, 3-50. 
artikel 28 bis $\$ 2$ Sv, ook uitstrekt tot de proactieve recherche, daar waar de inlichtingendiensten tot op vandaag nog steeds niet over een gelijkaardige wetgeving beschikken in het kader van de uitoefening van hun opdrachten en bevoegdheden. ${ }^{6}$

Tot op de dag van vandaag is de Veiligheid van de Staat dus aangewezen op informatie uit open bronnen, informatie die kan worden opgevraagd bij diverse openbare en private instellingen, informatie aangevoerd door derde diensten en, zeer belangrijk, de HUMINT47 - informatie afkomstig van bronnen.

De inlichtingendiensten zijn nochtans al jaren vragende partij van een dergelijke wetgeving, die niet enkel hoogstnoodzakelijk is om de dienst toe te laten op de meest performante manier de bedreigingen te kennen, te analyseren en tegen te gaan, maar die ook moet toelaten zich te hijsen op het niveau van de inlichtingendiensten van de andere landen en tegelijkertijd met zich kan brengen dat de Veiligheid van de Staat in mindere mate afhankelijk zou zijn van de door bevriende diensten aangeleverde inlichtingen.

Het uitblijven van een dergelijke wetgeving voor de inlichtingendiensten is op zich al een aanwijzing van het wantrouwen waarmee de diensten worden bejegend. Daarenboven is het,in het licht van hetgeen hoger werd uiteengezet,met name dat de uiteindelijke finaliteit toch gemeenschappelijk is voor de verschillende diensten, bevreemdend te noemen dat zeer verre-gaande bevoegdheden worden verleend aan de enen, terwijl deze totaal ontzegd worden aan de anderen. Dit is des te eigenaardiger omdat men, de oorspronkelijke finaliteiten indachtig, ook zou kunnen voorhouden dat de bevoegdheden die worden toegekend aan de politionele en gerechtelijke diensten zeer verregaand ingrijpen in het leven van individuele burgers (opsporing en strafrechterlijke veroordeling), daar waar dit in essentie niet de hoofdtaak is van de inlichtingendiensten.

Daartegenover staat dat de politionele en gerechtelijke finaliteiten voor de burger - en blijkbaar niet enkel voor hem maar ook voor de politici en beleidsverantwoordelijken - makkelijker identificeerbaar en begrijpelijk zijn dan die van een inlichtingendienst, zodat de aanwending van bijzondere opsporingsmethoden,wezen ze nog zeer intrusief, meteen ook makkelijker aanvaardbaar en verdedigbaar is.

De toenemende aandacht van de politiediensten voor de proactieve recherche in combinatie met de mogelijkheid - en tot op heden het monopolie - om bijzondere opsporingsmethoden te gebruiken, hebben ertoe geleid dat de aandacht van deze diensten zich ook is gaan toespitsen op handelingen en gedragingen die sterk aanleunen, zo niet zelfs behoren tot het activiteitendomein van de inlichtingendiensten.

46. Een wetsvoorstel betreffende de methoden voor het verzamelen van gegevens door de inlichtingen- en veiligheidsdiensten ligt momenteel ter behandeling in het Parlement. Het voorstel, dat naar analogie met de wetgeving voor de politiediensten de BIM-wet wordt genoemd, werd net voor het parlementair reces van de zomer 2009 goedgekeurd in de Senaat en zal thans worden hernomen door de Kamer.

47. Human intelligence. Andere vormen van inlichtingen zijn bijv. SIGINT (signal intelligence), OSINT (open sources intelligence), TECHINT (technical intelligence). 
De proactieve recherche werd in de Belgische strafvordering ingevoerd door de wet van 12 maart 1998 tot verbetering van de strafrechtspleging in het stadium van het opsporingsonderzoek en het gerechtelijk onderzoek ${ }^{48}$ en wordt in artikel 28 bis \$2 Sv als volgt gedefinieerd:

\begin{abstract}
'Het opsporingsonderzoek strekt zich uit over de proactieve recherche. Hieronder wordt verstaan, met het doel te komen tot het vervolgen van daders van misdrijven, het opsporen, het verzamelen, registreren en verwerken van gegevens en inlichtingen op grond van een redelijk vermoeden van te plegen of reeds gepleegde maar nog niet aan het licht gebrachte strafbare feiten, en die worden of zouden worden gepleegd in het kader van een criminele organisatie, zoals gedefinieerd door de wet, of misdaden of wanbedrijven als bedoeld in artikel goter, $\S \S 2,3$ en 4, uitmaken of zouden uitmaken. Het instellen van een proactieve recherche behoeft voorafgaande schriftelijke toestemming, door de procureur des Konings, de arbeidsauditeur, of de nationaal magistraat gegeven in het kader van hun respectieve bevoegdheid, onverminderd de naleving van de specifieke wettelijke bepalingen die de bijzondere opsporingstechnieken regelen.'
\end{abstract}

Reeds van bij de aanvang werd door sommige auteurs gewaarschuwd voor een verschuiving van het politiewerk naar het inlichtingenwerk. Zo betoogde D. Vandermeersch bij een hoorzitting in de senaat over het toen hangende wetsontwerp betreffende de bijzondere opsporingsmethoden 49 dat deze niet mochten worden ingezet tijdens de proactieve fase, omdat er dan zou worden gedaan aan 'fishingexpeditions' en aan inlichtingenwerk te doen onder de dekmantel van gerechtelijk werk.

Ook C. De Valkeneer waarschuwt in het kader van de terrorismebestrijding voor een vermenging van de genres, $5^{\circ}$ maar hanteert het als argument om een uitbreiding van de bevoegdheden en middelen van de inlichtingendiensten af te raden.

Dit brengt ons meteen tot de tweede factor die we reeds aanhaalden, met name de terrorismewetgeving. Zoals reeds aangehaald maakt het terrorisme deel uit van de bedreigingen die door de Veiligheid van de Staat dienen te worden opgevolgd.

Tegelijkertijd bestaat er in België een wetgeving betreffende de terroristische misdrijven (art. I37 tot en met I4Iter Sw) die zeer breed is en die maakt dat men zich bijzonder vlug bevindt op het vlak van de gerechtelijke aanpak, zodanig dat de politiediensten hun bijzondere aandacht dan ook aan deze problematiek wijden.

Dit heeft tot gevolg dat het politie- en gerechtelijk werk zich meer en meer is gaan interesseren aan handelingen en gedragingen die zich situeren in de fase die eigenlijk nog voorafgaat aan de proactieve fase.

Er worden analyses gemaakt van fenomenen, voorstudies, evoluties, dreigingsanalyses, profiling, zonder dat er van een effectieve aanwijzing van misdrijven of voorbereiding ervan kan worden gesproken. Ons inziens bevindt men zich hier ten

48. B.S., 2 april 1998.

49. Parl. St.,Senaat, 2002-2003, 2-I460/4, Io.

50. C. De Valkeneer, 'De strijd tegen het terrorisme: enkele overwegingen', Vigiles, november 2004, Io6. 
volle op het domein van het inlichtingenwerk en is het gevaar voor overlapping dus veel groter.

In deze context is het trouwens opmerkelijk dat de politiediensten zich weliswaar in algemene regel positief hebben uitgelaten over de toekenning van bijzondere middelen voor inlichtingenvergaring door de inlichtingendiensten, maar tegelijkertijd aandringen op twee dingen, met name het kunnen beschikken over dezelfde middelen ${ }^{5}$ enerzijds en het tot stand brengen anderzijds van een wetgeving betreffende de specifieke en uitzonderlijke methodes voor de verwerking van gegevens van bestuurlijke politie, de zogenaamde BAM-wetgeving.

Met een BAM-wetgeving zou het hek totaal van de dam zijn,want op dat ogenblik zou de politie, los van enige band met het plegen van misdrijven, aan zuivere inlichtingenvergaring en -verwerking gaan doen, hetgeen nu net de core business is van een inlichtingendienst.

Deze evolutie is niet eigen aan België. Jean-Louis Bruguière, Frans magistraat gespecialiseerd in terrorismebestrijding, schreef reeds in 1998 hieromtrent het volgende:

'A l'heure actuelle - et c'est un fait important - devant la montée du terrorisme et le caractère mutant du terrorisme islamique, l'osmose et l'imbrication fonctionnelle entre les services de renseignements et d'enquête, et les juges spécialisés, s'avèrent de plus en plus étroites, non pas pour des raisons juridiques, politiques voire même éthiques, mais parce que sous la pression de la menace, les services spécialisésd ont compris que pour gagner en efficacité, il fallait que l'ensemble des acteurs de la lutte agisse de façon concertée et que la dichotomie prévention-répression était un concept dépassé. ${ }^{52}$

Dat er een noodzaak is aan samenwerking en aan uitwisseling van informatie tussen politie- en inlichtingendiensten zal niemand ontkennen. Deze samenwerking bestaat trouwens op het terrein en wordt ook in een aantal teksten vastgelegd.

De vraag is evenwel of dit zo wel zo ver moet gaan als een osmose en een 'imbrication fonctionnelle'? Wordt hierdoor niet de eigenheid van de verschillende diensten ondermijnd en de specifieke finaliteiten van elk van hen miskend?53

Zoals reeds gezegd is de Veiligheid van de Staat een zuivere inlichtingendienst, zonder politionele bevoegdheden en wenst zij dat ook te blijven. Er kan anderzijds niet ontkend worden dat bepaalde evoluties maken dat op sommige domeinen het spanningsveld met de politie- en gerechtelijke diensten evident is. De ontwikkeling van de proactieve recherche, de uitbreiding van de terrorismewetgeving, de bevoegdheid van de Veiligheid van de Staat met betrekking tot criminele

5I. Hiermee wordt voornamelijk gefocust op de methode van hacking die aan de inlichtingendiensten wordt gegeven in het wetsvoorstel op de BIM en waarover de politiediensten in het kader van de BOM-wet niet beschikken.

52. J.-L. Bruguière, 'Renseignement et lutte antiterrorisme', in P. Lacoste (ed.), Le renseignement à la française, Parijs, Economica, I998, 27I.

53. W. Van Laethem, 'De verhouding tussen inlichtingendiensten en het gerecht gisteren, vandaag en morgen', Vigiles, mei 2007 , I-6. 
organisaties ${ }^{54}$ hebben inderdaad ontegensprekelijk tot gevolg dat politie- en inlichtingenwerk in bepaalde materies meer op mekaar is afgestemd dan in andere.

De mechanismen en regelgevingen bestaan trouwens om deze samenwerking op de meest optimale manier te laten verlopen.

Het debat over de verhouding tussen de politie- en inlichtingendiensten en hun samenwerking kan in België ook niet los van sommige historische gebeurtenissen worden gevoerd.

Zoals uit het historisch overzicht reeds bleek is de Veiligheid van de Staat, voornamelijk in de jaren '80 en ' 90 , geconfronteerd geweest met een aantal gebeurtenissen die de dienst in een zeer negatief daglicht stelden en aanleiding hebben gegeven tot een aantal parlementaire onderzoekscommissies.

Een aantal politieke partijen hebben toen zonder veel omhaal gepleit voor de afschaffing van de Veiligheid van de Staat en het doen opgaan van de dienst in de toen nog op te richten ééngemaakte politie. Af en toe wordt dit scenario nog eens opgevoerd, zij het met weinig succes, maar het wijst er wel op dat het niet uitgesloten is dat de discussie over de aflijning van de bevoegdheden, de uitwisseling van de informatie en de samenwerking tussen de onderscheiden diensten niet louter academisch is.

Daarenboven stelt men in deze discussie ook een slingerbeweging vast: daar waar sommigen ooit zoals net uiteengezet de eenvoudige afschaffing van de inlichtingendienst voorop stelden en de versmelting ervan met de ééngemaakte politie, 55 stelt men thans, in het kader van de discussies over de BIM-wetgeving een omgekeerde tendens vast. De besprekingen in de senaat hebben inderdaad aan het licht gebracht dat bij sommige senatoren de vrees zou bestaan dat de Veiligheid van de Staat zou geïnstrumentaliseerd worden door de politie- en gerechtelijke diensten, die de BIM-methoden zouden wensen te gebruiken in het kader van hun gerechtelijke onderzoeken. Deze vrees komt ons ongegrond voor, in de mate dat de leden van de inlichtingendiensten geen officieren van gerechtelijke politie zijn en niet kunnen worden ingezet onder het gezag van de gerechtelijke overheden, zelfs niet in het kader van de technische bijstand.

De autonomie, de eigenheid en de eigen finaliteit van de inlichtingendienst lijken ons buiten kijf te staan en de toekenning aan de inlichtingendiensten van eigen methoden om de inlichtingen te vergaren lijken dan ook het eindpunt te zijn in deze discussie.

Dit neemt niet weg dat er tussen inlichtingendiensten en politionele en gerechtelijke overheden uiteraard een interactie bestaat, die zich op verschillende vlakken uit:

54. Alhoewel ook hier een duidelijk onderscheid te maken valt tussen hetgeen de inlichtingendienst op dit vlak doet in vergelijking met de politie of het gerecht. De Veiligheid van de Staat benadert de problematiek van de criminele organisaties vanuit een middellange- of langetermijnvisie, waarin de nadruk ligt op het inzicht verwerven in fenomenen, structuren en hun evolutie en de bedreigingen die dit met zich meebrengt voor de democratische rechtsorde. Er worden dus geen doelgerichte opsporingen gedaan naar wel bepaalde misdrijven.

55. Of een aantal varianten hierop, zoals bijv. de versmelting van de militaire en de burgerlijke inlichtingendienst. 
de aangifte van misdrijven, de uitwisseling van informatie, de ondersteuning door de inlichtingendienst van een opsporings- of gerechtelijk onderzoek, de samenloop tussen een dergelijk onderzoek en het onderzoek gevoerd door een inlichtingendienst, het gebruik in rechte van de informatie aangereikt door de inlichtingendienst met daarbijhorend de problematiek van de classificatie van de informatie

We zullen deze verschillende items hierna bespreken, waarbij de toestand zowel de lege lata als de lege ferenda zal worden bekeken, aangezien de op stapel staande BIMwetgeving hierop een zeer duidelijke invloed zal gaan hebben.

\section{De samenwerking tussen inlichtingendienst en gerechtelijke overheid}

\section{I Algemene opmerkingen}

De Veiligheid van de Staat levert, zoals reeds gezegd, geen brute informatie aan (raw intelligence), maar analyseert en verwerkt inlichtingen tot een afgewerkt product dat alsdan aan verschillende instanties wordt overgemaakt. De informatiestroom kan uiteraard verschillende vormen aannemen, naargelang de bestemmeling, de aard van de informatie, het gebruik dat ervan kan of mag gemaakt worden, de oorsprong ervan, de classificatie en dergelijke meer.

De gerechtelijke overheid is dus niet de enige - en indien we een becijferde analyse zouden gaan maken - zeker niet de belangrijkste partner van de inlichtingendienst. Maar het is uiteraard wel een belangrijke partner in de zin dat de aangeleverde informatie kan worden gebruikt in een opsporings- of gerechtelijk onderzoek en dus als bewijsmateriaal kan worden aangewend.

Wie spreekt van bewijs, heeft het uiteindelijk over een rechtsgang ten gronde, publiek, tegensprekelijk, met alle garanties die het EVRM aan dergelijke procedures verstrekt.

Hiermee willen we duidelijk maken dat bij de overgang van informatie van de inlichtingenwereld naar de gerechtelijke het spanningsveld zeer groot kan zijn en er tegengestelde belangen kunnen spelen, zodanig dat er duidelijke regels en afspraken dienen te worden gemaakt die in de mate van het mogelijke deze twee belangen met mekaar verenigen.

Er zijn daarenboven een aantal regels inherent aan de inlichtingendiensten die hierbij moeten worden gerespecteerd. Vooraleer we hier evenwel op ingaan, dringen zich een aantal voorafgaandelijke opmerkingen op.

Het verzamelen van inlichtingen heeft te maken met gebruik van en dus ook de bescherming van menselijke bronnen, het beschikken over informatie afkomstig van buitenlandse inlichtingendiensten en dus beschermd door de regel van de derde dienst, terwijl de procedure voor de strafrechter ten gronde hoofdzakelijk beheerst wordt door de regels van de tegensprekelijkheid.

De overgang van intelligence naar strafrechterlijk bruikbaar bewijsmateriaal is dus een zeer delicaat probleem, waarbij een aantal fundamentele problemen ter 
sprake komen zoals daar zijn bronbescherming, fundamentele rechten van de verdediging, tegenstelbaarheid, bewijskracht, bescherming van operationele technieken en meer in het algemeen de vraag waaraan de Belgische wetgever de voorrang en de primauteit geeft, de staatsveiligheid of het strafproces.

Vooraleer de regelgeving te overlopen met betrekking tot de overgang van informatie van een inlichtingendienst naar een gerechtelijke overheid, dringt een laatste opmerking zich op.

Er blijken inderdaad fundamentele verschillen in benadering en regelgeving te zijn tussen Nederland en België op het niveau van de problematiek van de primauteit staatsveiligheid versus strafproces.

Wanneer men de beide diensten met mekaar vergelijkt, dan stelt men een grote gelijklopendheid vast: grosso modo dezelfde bevoegdheden, inlichtingendiensten zonder politionele bevoegdheid, dezelfde scheiding in finaliteiten tussen inlichtingendienst en politie en gerecht, de lege ferenda zelfs een BIM-wetgeving die haar inspiratie heeft gevonden in de Nederlandse wetgeving..$^{6}$

En toch dient men tot de vaststelling te komen dat er op het niveau van de uiteindelijke verhoudingen tussen staatsveiligheid en strafproces een fundamenteel verschil lijkt te bestaan in aanpak tussen België en Nederland.

Men kan zich inderdaad niet van de indruk ontdoen dat in België de nadruk nog steeds ligt op de strafrechterlijke aanpak die lijkt geprivilegieerd te worden ten opzichte van de intelligence werkwijze. Indien de uiteindelijke keuze dient te worden gemaakt tussen hetgeen primeert, te weten een strafrechterlijke veroordeling of de belangen van de staatsveiligheid, op het risico dat sommige misdrijven niet zouden worden berecht, kiest het Belgisch systeem voor het strafrecht. Dit komt tot uiting in de regelgeving betreffende de informatieovergang naar het gerechtelijk niveau die, wanneer het gaat om de aanduiding dat er strafbare feiten werden gepleegd, verplicht is.

Men ontwaart ons inziens dezelfde verhouding in de regels die betrekking hebben op het gelijklopend onderzoek van een inlichtingendienst en dat van een gerechtelijke overheid.

Men stelt het eveneens vast in de BIM-wetgeving zelf,waarvan de achterliggende filosofie vaak teveel is ingegeven door de BOM-wetgeving en de daardoor geïmpliceerde gerechtelijke finaliteit.

Ook de debatten in de Senaat zelf hebben aangetoond dat er in de geest van de parlementairen een zekere verwarring bestaat nopens de juiste afbakening van bevoegdheden, zodat de Veiligheid van de Staat soms nog wordt gepercipieerd als een soort politiedienst of minstens een dienst met een gerechtelijke finaliteit. Dit legt ook uit waarom blijkbaar de vrees bestaat bij sommige parlementsleden dat de inlichtingendienst zou gebruikt of 'misbruikt' worden door de gerechtelijke overheden, die een beroep zouden willen doen op de bijzondere inlichtingenmethoden voor hun gerechtelijk onderzoek. Hetgeen hier wordt aangekaart, is eigenlijk

56. Parl. St. Senaat, 2008-2009, nr. 4-I053/I, Memorie van toelichting. 
de problematiek van het beweerd gebruiken van de aan de inlichtingendienst toegekende methoden voor een gerechtelijke finaliteit, daar waar de gerechtelijke overheden hun eigen BOM-methoden niet of nog niet zouden kunnen aanwenden.

We komen hierop nog terug, maar de gestelde hypothese is wel sprekend voor de machtsverhouding tussen inlichtingendienst en gerechtelijke overheid.

\subsection{Verplichte ambtelijke aangifte bij strafbare feiten 57}

Wanneer we het hebben over de overgang van informatie van de inlichtingendiensten naar de gerechtelijke overheden, dient een onderscheid te worden gemaakt naargelang de overgemaakte informatie betrekking heeft op het plegen van strafrechterlijke inbreuken of niet.

Artikel 29 van het Wetboek van strafvordering luidt als volgt:

'Iedere gestelde overheid, ieder openbaar officier of ambtenaar die in de uitoefening van zijn ambt kennis krijgt van een midaad of van een wanbedrijf, is verplicht daarvan dadelijk bericht te geven aan de procureur des Konings bij de rechtbank binnen wier rechtsgebied die misdaad of dat wanbedrijf is gepleegd of de verdachte zou kunnen worden gevonden, en aan die magistraat alle desbetreffende inlichtingen, processenverbaal en akten te doen toekomen.'

Aangezien de leden van de inlichtingendienst ambtenaren zijn,,$^{8}$ zijn ze op basis van dit artikel verplicht59 de gerechtelijke overheden in kennis te stellen wanneer uit inlichtingen waarover ze beschikken zou blijken dat er een misdrijf werd gepleegd en beschikt de Veiligheid van de Staat ter zake dus niet over een opportuniteitsappreciatie.

De vraag kan worden gesteld of de toepassing van artikel 29 Sv voor de inlichtingendiensten wel wenselijk is en alleszins of het een verplichting dient te zijn. Onafgezien nog van het feit dat het artikel aangeeft dat er een primauteit bestaat voor de gerechtelijke finaliteit, kan deze regel een belemmering vormen voor het effectief verder zetten van het inlichtingenwerk.

Opvallend is dat in andere landen deze regel niet op dezelfde manier wordt toegepast. Zo houdt in het Verenigd Koninkrijk de Service Security Act van 1998 in dat 'no information is disclosed by (the service) except so far as necessary (...) for the purpose of preventing or detecting serious crime'.

Ook in Nederland is de situatie anders, aangezien er daar geen verplichting bestaat om gegevens die van belang kunnen zijn voor de opsporing en vervolging van strafbare feiten over te maken.

57. L. Huybrechts, 'Aangifte van misdrijven', in Commentaar strafrecht en strafvordering (Comm.Straf.), 7-9.

58. Vr. en Antw., Kamer, 2I februari ig9o.

59. De voorbereidende werken van de wet van 30 november 998 laten er geen twijfel over bestaan dat deze verplichting blijft bestaan,ongeacht het feit dat deze wet een specifieke regeling in het leven riep voor de informatieoverdracht naar het gerecht. Zie Parl. St., Senaat, I997-I998, 758/I0,37. 
Deze regeling, die haar neerslag vindt in artikel 38 van de Nederlandse wet op de inlichtingen- en veiligheidsdiensten van 7 februari 2002, werd als volgt gemotiveerd:

'In artikel 38 , eerste lid, wordt allereerst bepaald dat indien bij de verwerking van gegevens door of ten behoeve van een dienst blijkt van gegevens die tevens van belang kunnen zijn voor de opsporing en vervolging van strafbare feiten, daarvan door de betrokken minister of namens deze het hoofd van de dienst schriftelijk mededeling kan worden gedaan aan het daartoe aangewezen lid van het openbaar ministerie, onverminderd het geval dat daartoe een wettelijke verplichting bestaat. Voorop staat in dit artikel dat een dergelijke mededeling kan worden gedaan; het betreft hier derhalve een discretionaire bevoegdheid van de betrokken minister.

Bij de taakuitvoering van de diensten en de verwerking van gegevens in dat verband komt het immers meer dan eens voor, dat men daarbij stuit op strafbare feiten. Het zou echter aan een goede taakuitvoering door de diensten, in het bijzonder de door hen te behartigen belangen, in de weg staan, indien telkens van een geconstateerd strafbaar feit mededeling zou moeten worden gedaan. Temeer nu de mededeling ertoe kan leiden dat het openbaar ministerie tot opsporing en vervolging overgaat, waarbij dan mogelijk het eigen onderzoek van de dienst in gevaar kan komen. De minister moet derhalve ruimte worden gelaten, om een eigen afweging te maken. Het spreekt voor zich dat als er sprake is van ernstige misdrijven, de ruimte om te beslissen daar vervolgens geen mededeling over te doen uitermate klein - zo niet nihil - wordt. ${ }^{60}$

De verplichting opgelegd door artikel $29 \mathrm{~Sv}$ is zeer verregaand,vermits zij betrekking heeft op om het even welke misdaad of wanbedrijf waarvan de ambtenaar in de uitoefening van zijn functie kennis krijgt. Dit houdt dus in dat indien tijdens een observatie, een schaduwing, een operatie, misdrijven aan het licht zouden komen, deze schriftelijk moeten gemeld worden en best ook zo snel mogelijk.

Het lijkt nogal evident dat dit in bepaalde gevallen de operationaliteit van de dienst kan schaden en ook dat deze verplichte kennisgeving het verdere verloop van het inlichtingenwerk in het gedrang kan brengen. Het valt hierbij ook op dat de regel betreffende de gelijklopende gerechtelijke en inlichtingenonderzoeken (zie hierna) alleen in één enkele richting wordt geponeerd, te weten dat het inlichtingenonderzoek geen schade mag toebrengen aan een lopend opsporings- of gerechtelijk onderzoek. Nochtans lijkt het vrij duidelijk dat de strikte toepassing van deze verplichting een gevaar kan inhouden voor het prijsgeven van operationele informatie, gevaar voor bronnen, gevaar voor de werking van de dienst.

Het is nu wel zo dat er op de niet-naleving van deze aangifteverplichting geen strafsanctie bestaat - hoogstens een disciplinaire -, maar de praktijk wijst toch uit dat de vraag wordt gesteld naar de wijze van naleving van deze verplichting door de inlichtingendiensten en de controle erop.

6o. Tweede Kamer, vergaderjaar 1997-I998, 25 877, nr.3 58. 
Het ware beter geweest een systeem te bedenken waarin de aangifte geen verplichting is maar een mogelijkheid, waarbij ook nog ruimte overblijft voor een efficiënt voortzetten van het inlichtingenonderzoek.

De problematiek zal daarenboven de lege ferenda bijzonder belangrijk gaan worden. We hebben het reeds gehad over de toename van de proactieve recherche alsmede over de uitbreiding van strafbaarstellingen in materies zoals terrorisme, georganiseerde criminaliteit, financieciering van terrorisme. De proactieve recherche maakt dat de politie- en gerechtelijke diensten opschuiven naar het inlichtingendomein, terwijl de zeer ruime strafrechterlijke definities van terrorisme of de incriminaties op het vlak van criminele organisaties maken dat de inlichtingendiensten zich vrij vlug gaan bevinden in de penale sfeer.

De toekenning van de BIM-methoden zal daarenboven maken dat de inlichtingendiensten in de mogelijkheid zullen gesteld worden om veel vlugger bijzonder interessante informatie te verzamelen, maar de vraag die zich dan zal stellen is te weten op welk vlak die informaties op dat ogenblik het meest interessant en relevant zijn.

De antiterrorismewetgeving in het Belgisch strafrecht is bijzonder breed, onder andere op het vlak van de deelname aan een terroristische organisatie, ${ }^{6 \mathrm{I}}$ die geen bijzondere positieve daden veronderstelt.

Indien bijvoorbeeld de inlichtingendienst bij een telefoontap informatie bekomt over een dergelijke deelname is er,in de zin van artikel 29 Sv een aanwijzing van het plegen van een misdrijf en dus een verplichting tot aangifte.

Maar wat is op dit ogenblik in een dergelijk scenario de meerwaarde van een aangifte? Is ze zelfs niet eerder contraproductief? Bestaat het risico niet dat een potentieel veelbelovend inlichtingenonderzoek vroegtijdig moet worden afgebroken op een ogenblik dat er strafrechterlijk onvoldoende elementen voorhanden zijn om met enige kans op slagen een gerechtelijk onderzoek te starten?

Maar de op stapel staande BIM-wetgeving gaat nog een stap verder.

Niet alleen wordt het principe van de verplichte ambtelijke aangifte op basis van artikel 29 Sv behouden, het wordt zelfs uitgebreid. Er wordt inderdaad voorzien dat in de wet op de inlichtingendiensten een artikel I9/I wordt ingevoerd waarvan de eerste paragraaf als volgt luidt :

'Wanneer de aanwending van de specifieke of uitzonderlijke methoden ernstige aanwijzingen aan het licht brengt over het plegen van een misdaad of wanbedrijf of, op grond van een redelijk vermoeden wijst op te plegen of reeds gepleegde maar nog niet aan het licht gebrachte strafbare feiten, brengen de betrokken diensten dit onverwijld ter kennis aan de commissie met het oog op de toepassing van artikel 29 van het Wetboek van strafvordering. Deze commissie onderzoekt de verzamelde gegevens ongeacht de wijze waarop ze vastgelegd werden.'

6r. Artikelen 137 e.v. Sw. 
De bedoeling van de verwittiging van de commissie is deze toe te laten, via een nietgeclassifieerd proces-verbaal de gerechtelijke overheden te verwittigen.

De hiervoor in het cursief aangegeven tekst verwijst eigenlijk naar het artikel $28 \mathrm{bis}$ \$2 Sv dat de proactieve recherche definieert en legt dus aan de inlichtingendienst op om 'onverwijld' een ambtelijke aangifte te doen indien er een redelijk vermoeden bestaat dat feiten zullen worden gepleegd of gepleegd zijn maar nog niet aan het licht kwamen.

Dit betekent ons inziens een zeer grote verstoring van het werk van de inlichtingendienst aangezien er hier wordt opgelegd om, vaak in een zeer vroege fase van het inlichtingenwerk, de overstap te maken naar het gerechtelijke. Daarenboven brengt dit met zich mee dat de inlichtingendienst automatisch aan de oorsprong gaat liggen van de proactieve recherches in het kader van het opsporingsonderzoek.

Dit lijkt ons strijdig te zijn met de afzonderlijke en verschillende finaliteiten van deze onderderscheiden diensten. Te noteren valt dat het Vast Comité ${ }^{62}$ al op dit moment de Veiligheid van de Staat verwijt te werken voor de gerechtelijke autoriteiten en politiediensten bij de uitoefening van de technische bijstand (zie hierna) en de mening is toegedaan dat een absolute aangifteverplichting te verregaand is.

Er werd gepleit voor een meer soepele regeling die moest toelaten in elk concreet geval de beste weg (gerechtelijke of inlichtingen) te kiezen.

Het is dan ook niet verwonderlijk dat door het Comite I een amendement werd voorgesteld dat ertoe strekt de Commissie toe te laten in functie van de aard van de gepleegde of te plegen feiten en in functie van de goede werking van de inlichtingenen veiligheidsdienst te beoordelen wanneer de gerechtelijke instanties zullen worden verwittigd en dus het principe van de uitgestelde ambtelijke aangifte huldigt. Dit amendement werd, vooralsnog, niet weerhouden.

Nochtans ging dit amendement in de zin van hetgeen in het wetsontwerp dat tijdens de vorige legislatuur werd neergelegd ${ }^{6} 3$ ter zake was opgenomen. Wanneer we trouwens in de parlementaire documenten met betrekking tot dit voorstel herhaaldelijk kan lezen dat politie- en inlichtingendiensten onderscheiden finaliteiten hebben en dat dat onderscheid dient te worden gevrijwaard, kan een regeling zoals ze thans is ontworpen enkel verbazing oproepen.

\subsection{Aangifte buiten het plegen van strafbare feiten}

Inlichtingendiensten hebben zoals reeds gezegd hun eigen finaliteit, die niet politioneel en gerechtelijk is, zodanig dat een groot gedeelte van de overgemaakte informatie niet daarop slaat en ook niet als bestemmeling de gerechtelijke diensten heeft.

Artikel ig WIV luidt als volgt:

'De inlichtingen- en veiligheidsdiensten delen de inlichtingen bedoeld in artikel I3, tweede lid, slechts mee aan de betrokken ministers en de betrokken gerechtelijke

62. Vast Comité I, Activiteitenverslag 2004, Antwerpen-Oxford, Intersentia, II4.

63. Wetsontwerp betreffende de methoden voor het verzamelen van gegevens door de inlichtingenen veiligheidsdiensten, Parl. St. Senaat, 2006-2007, 3-2138/I. 
en administratieve overheden, aan de politiediensten en aan alle bevoegde instanties en personen vereenkomstig de doelstellingen van hun opdrachten alsook aan de instanties en personen die het voorwerp zijn van een bedreiging bedoeld in de artikelen 7 en II.'

Artikel $20 \mathrm{WIV}, \S 3$ stelt het volgende:

'§ 3. Het Ministerieel Comité bepaalt de in artikel rg, eerste lid, bedoelde voorwaarden waaronder de inlichtingen worden meegedeeld en de voorwaarden van de in § I van dit artikel bedoelde samenwerking.'

Inlichtingendiensten maken dus met name hun informatie over aan allerhande overheidsinstanties, hetgeen trouwens hun core business is.

Maar dit neemt niet weg dat ook de gerechtelijke overheden, ook buiten de aangifte van misdrijven, informatie kunnen krijgen van de inlichtingendiensten.

Men kan discussiëren over de vraag of het hier om een mogelijkheid dan wel om een verplichting gaat, ${ }^{6}$ maar deze discussie lijkt ons vrij academisch, alhoewel het toch wel opvallend is dat de informatieverstrekking in de omgekeerde zin toch enigszins anders wordt geformuleerd.

Artikel I4 WIV luidt namelijk als volgt:

'Met inachtneming van de wet, op basis van de eventueel afgesloten akkoorden en de door hun verantwoordelijke overheid bepaalde regels kunnen de gerechtelijke overheden, de ambtenaren en agenten van de openbare diensten uit eigen beweging aan de betrokken inlichtingen- en veiligheidsdienst de inlichtingen meedelen die nuttig zijn voor de uitvoering van zijn opdrachten.

Op verzoek van een inlichtingen- en veiligheidsdienst kunnen, met inachtneming van de wet en op basis van de eventueel afgesloten akkoorden en van de door hun verantwoordelijke overheid bepaalde regels, de gerechtelijke overheden, de ambtenaren en agenten van de openbare diensten aan de betrokken inlichtingen en veiligheidsdienst de inlichtingen meedelen die nuttig zijn voor de uitvoering van zijn opdrachten.

Wanneer de gerechtelijke overheden, de ambtenaren en de agenten van de openbare diensten van oordeel zijn dat ze de door de inlichtingendiensten gevraagde inlichtingen niet kunnen meedelen, geven zij daarvoor binnen en maand na de aanvraag schriftelijk de redenen op.'

Het gaat hier duidelijk om een mogelijkheid, een toelating en dus geen verplichting. Het wijst er alleszins op dat in België de primauteit ligt bij de strafvordering en dat het geheim van het opsporings- en gerechtelijk onderzoek prevaleert over het geheim van informatie van inlichtingendiensten.

Ook over de juiste draagwijdte van de term 'hun opdrachten' kan worden geargumenteerd: ${ }^{65}$

64. Vast Comité I, Activiteitenverslag 2004, II8.

65. Alhoewel ook hier het Comité de vraag stelt of hun opdrachten slaat op die van de bestemmelingen dan wel van de inlichtingendiensten. 
gaat het om inlichtingen die kaderen in de opdrachten van de bestemmelingen of in die van de inlichtingenopdrachten, of in beide? Ook hier lijkt de discussie veelal academisch aangezien het ons toch voorkomt dat het legaliteitsbeginsel voor de twee geldt.

Het gaat hier in se om andere inlichtingen dan diegene die kaderen in de ambtelijke aangifte, aangezien het zich om niet-misdrijfgebonden informatie handelt. Dit kan betrekking hebben op inlichtingen die bijvoorbeeld situaties betreffen die een voedingsbodem kunnen vormen voor bepaalde misdaadfenomenen, zoals bijvoorbeeld de criminele organisaties.

Wel zou de richtlijn die het Ministerieel Comité voor inlichting en veiligheid in uitvoering van artikel 20, $\S 3$, zou moeten nemen, een verplichting in het leven kunnen roepen, maar deze richtlijn blijkt vooralsnog niet te bestaan.

Op juridisch vlak levert dit ons inziens evenwel geen probleem op bij de overdracht van informatie naar het gerecht gelet op de zeer extensieve interpretatie van het Hof van Cassatie inzake eventueel onrechtmatig verkregen bewijs.

Alhoewel er geen richtlijn is van het Ministerieel Comité, heeft de regeling van artikel I9 en 20 WIV wel aanleiding gegeven tot een aantal gemeenschappelijke omzendbrieven van de Minister van justitie en het College van procureurs-generaal, ${ }^{66}$ een aantal protocolakkoorden ${ }^{67}$ en verschillende overlegplatforms uitgewerkt in een aantal Koninklijke Besluiten. ${ }^{68}$

\subsection{Conformiteit met artikel 8 van het EVRM en artikel 22 van de Grondwet}

Wanneer er inlichtingen worden verzameld betekent dit uiteraard een inbreuk op in het privéleven van de burger en een dergelijke inmenging is in principe zowel overeenkomstig de nationale als de internationale wetgeving verboden.

Artikel 8 EVRM met betrekking tot het recht op eerbiediging van privé-, familieen gezinsleven zegt het volgende:

'I. Eenieder heeft recht op eerbiediging van zijn privé leven, zijn gezinsleven, zijn huis en zijn briefwisseling.

2. Geen inmenging van enig openbaar gezag is toegestaan met betrekking tot de uitoefening van dit recht dan voor zover bij de wet is voorzien en in een democratische samenleving nodig is in het belang van 's lands veiligheid, de openbare veiligheid, of het economisch welzijn van het land, de bescherming van de openbare orde en het voorkomen van strafbare feiten, de bescherming van de gezondheid of de goede zeden, of voor de bescherming van de rechten en vrijheden van anderen.'

66. COL 9/2005 van I5 juli 2005 betreffende de gerechtelijke aanpak van het terrorisme; COL I2/2005 betreffende de samenwerking tussen de Veiligheid van de Staat en de Algemene Dienst Inlichtingen en Veiligheid van de krijgsmacht en de gerechtelijke overheden.

67. Protocolakkoorden met Federaal Parket, met ADIV, met het gevangeniswezen.

68. Zie lijst hiervan onder artikel 20 W.ISV, Codex Inlichtingendiensten, Die Keure. 
Artikel 22 van de Grondwet stelt:

'Ieder heeft recht op de eerbiediging van zijn privé-leven en zijn gezinsleven, behoudens in de gevallen en onder de voorwaarden door de wet bepaald. De wet, het decreet of de in artikel I34 bedoelde regel waarborgen de bescherming van dat recht.'

De vraag die gesteld moet worden is dus of het overmaken van inlichtingen een voldoende wettelijke basis vindt in de in Belgisch recht ter zake vigerende bepalingen.

De wet die een dergelijke inmenging voorziet dient duidelijk en toegankelijk te zijn en de inbreuk op het privéleven moet strikt noodzakelijk zijn voor het behoud van een democratische samenleving, zoals vereist wordt door de rechtspraak van het EHRM.

Het komt ons voor dat in het kader van het artikel $29 \mathrm{~Sv}$ deze wettelijke basis aanwezig is en voldoende duidelijk. Er is tevens een legitiem doel en de inbreuk op het privéleven staat in verhouding tot dit doel.

Ook voor wat betreft het overmaken van inlichtingen buiten diegene die betrekking hebben op strafbare feiten lijkt artikel ig van de WIV een voldoende rechtsbasis te verstrekken.

De problematiek van de inbreuken op het privéleven zal uiteraard de lege ferenda in belang gaan toenemen indien de Veiligheid van de Staat inderdaad zal kunnen beschikken over een reeks bijzondere methoden die een belangrijke intrusie vormen in het privéleven en derhalve bijzonder dienen te worden gereglementeerd.

De indieners van het wetsvoorstel hebben dan ook zorgvuldig gewaakt over de naleving van de bepalingen van het EVRM en de principes voortspruitende uit de rechtspraak van het EHRM. ${ }^{69}$

Volgens B. Lombaert ${ }^{70}$ 'l'accessibilité de la loi est la possibilité pour le citoyen de disposer de renseignements suffisants sur les règles de droit applicables'. De wet is duidelijk wanneer de termen die ze hanteert de burger in staat stellen zonder dubbelzinnigheid de gevolgen in te schatten van haar toepassing. Het Europees Hof aanvaardt evenwel dat het niveau aan duidelijkheid van de wet minder kan zijn in het domein van de nationale veiligheid dan in andere domeinen. ${ }^{71}$ Het Hof is in dit geval niettemin van oordeel dat de wet voldoende duidelijke termen dient te hanteren, waarbij ze op een adequate manier aangeeft onder welke omstandigheden en volgens welke voorwaarden ze het openbaar gezag een inmenging in de persoonlijke levenssfeer toestaat.

De beperktheid van de middelen waarover de inlichtingendiensten totnogtoe konden beschikken heeft met zich gebracht dat er zeer weinig rechtspraak bestaat met betrekking tot deze problematiek. Alleszins lijkt de wetgever een systeem te hebben ingebouwd dat gestoeld is op het vinden van het zeer delicate evenwicht tussen de

69. Arrest Rotaru t. Roemenië van 4 mei 2000 (dat betrekking had op een inlichtingendienst); Arrest Klas t. Duitsland van 18 november 1977.

70. B. Lombaert, 'Discipline à l'armée, ordre illégal et vie privée', noot onder Raad van State, 30 juni I995, Rev. trim. D.H., I996, 308, die naar de arresten Sunday Times van 26 april 1979 en Malone van 2 augustus 1984 van het Europees Hof verwijst.

7I. Arrest Leander t. Zweden van 26 maart 1987. 
bescherming van de fundamentele bebelangen van de Staat en de bescherming van de fundamentele rechten en vrijheden van de mens. Daarom worden deze methoden aan een strikte controle onderworpen, die strenger wordt naarmate die methode afbreuk doet aan deze fundamentele rechten. De methode moet onmiddellijk worden stopgezet, als het doel waarvoor zij wordt aangewend bereikt is of als het doel met een minder ingrijpende methode kan worden bereikt.

De Memorie van Toelichting bij het wetsvoorstel geeft duidelijk aan ${ }^{72}$ dat het de Nederlandse wet van 7 februari 2002 is die als voorbeeld heeft gediend voor de Belgische tekst, zodat de Nederlandse rechtspraak mutatis mutandis met belangstelling zal kunnen worden in aanmerking genomen.

De effectieve toepassing van de wet zal uiteraard aanleiding geven tot rechtspraak die moet toelaten de juiste afweging te maken van de in conflict zijnde belangen, maar het lijkt ons vooralsnog overdreven en ietwat suggestief van de op stapel staande wetgeving te kwalificeren als de Belgische Patriot Act. ${ }^{73}$

\subsection{Samenwerking, medewerking en technische bijstand}

De samenwerking, medewerking en technische bijstand worden behandeld in het artikel 20 W.I.V. dat we hier in zijn totaliteit weergeven:

'\$ I. De inlichtingen- en veiligheidsdiensten, de politiediensten, de administratieve
en gerechtelijke overheden zorgen voor een zo doeltreffend mogelijke wederzijdse
samenwerking. De inlichtingen- en veiligheidsdiensten zorgen er eveneens voor dat er
samenwerking is met de buitenlandse inlichtingen- en veiligheidsdiensten.
§ 2 . Wanneer ze daartoe door hen aangezocht worden kunnen de inlichtingen- en vei-
ligheidsdiensten, binnen de perken van een protocol goedgekeurd door de betrokken
ministers, hun medewerking en in het bijzonder hun technische bijstand verlenen aan
de gerechtelijke en bestuurlijke overheden.
§ 3 . Het Ministerieel Comité bepaalt de in artikel I9, eerste lid, bedoelde voorwaarden
waaronder de inlichtingen worden meegedeeld en de voorwaarden van de in $§$ I van dit
artikel bedoelde samenwerking.'

Het artikel is in zeer algemene termen opgesteld en bevat ook geen definitie van hetgeen onder technische bijstand dient te worden begrepen en geldt dus eerder als een intentie- en principeverklaring.

Daarenboven dient erop te worden gewezen dat er geen protocol werd goedgekeurd door de betrokken ministers, hetgeen evenwel geen formeel bezwaar betekent voor de vooropgestelde samenwerking.

De voorbereidende werkzaamheden van de wet van 30 november $1998{ }^{74}$ stellen terzake dat deze bepaling 'de wettelijke grondslag vast(legt) die de gerechtelijke

72. Parl. St. Senaat, 2008-2009, 4-I053/I, II.

73. W. Desmedt, 'Een Belgische Patriot Act', Juristenkrant, II februari 2009.

74. Parl.. St., Senaat, I997-98, 758/3, I2; Parl. St., Senaat, 758/Io, I997-98, II5; Parl. St., Kamer, I998-99, 638/20, 5 ; Parl. St., Senaat, I997-98, 758/10, 37. 
en bestuurlijke overheden toelaat de medewerking alsook de technische bijstand van de inlichtingen- en veiligheidsdiensten te verzoeken, namelijk als expert, in het kader van verhoren, ambtelijke opdrachten, huiszoekingen, taakgerichte analyses en adviezen' en dat het 'inzake proactief onderzoek (...) duidelijk [is] dat de Veiligheid van de Staat niet gemachtigd is om op autonome wijze een proactief onderzoek te voeren zoals bepaald is in het kader van de wet-Franchimont. De Veiligheid van de Staat kan evenwel haar steun verlenen aan een project van proactief onderzoek op grond van haar gespecialiseerde kennis. Deze steun moet echter strikt beperkt blijven tot het vervullen van haar eigen wettelijke taken en mag in geen geval speurwerk inhouden dat gericht is op specifieke strafbare feiten'.

De hierbij gebezigde term 'expert' kan evenwel aanleiding geven tot verwarring.

Er moet hier inderdaad worden verwezen naar de COL I2/200575 van 5 oktober 2005 van het College van Procureurs-generaal bij de Hoven van Beroep en die gewijd is aan de vormen van samenwerking tussen de gerechtelijke overheden en de inlichtingen- en veiligheidsdiensten.

In deze omzendbrief wordt aangegeven dat de technische medewerking kan worden gevraagd zowel door het openbaar ministerie als door een onderzoeksrechter, maar er wordt net de nadruk op gelegd dat de gespecialiseerde medewerking niet de aanduiding als deskundige impliceert. Hiermee wordt evenwel vooral de formele problematiek van de eedaflegging als deskundige geviseerd, hetgeen niet wegneemt dat de leden van de inlichtingendienst die worden aangezocht om deze bijstand te verlenen net omwille van hun know-how en hun expertise worden ingezet.

Indien zij nadien evenwel toelichting zouden dienen te komen geven bij de vonnisrechter zullen zij de eed afleggen als getuige.

Wat nu de juiste aard betreft van deze bijstand spreekt de COL I2/2005 van taakgerichte analyses, adviezen, samenwerking in het kader van verhoren, huiszoekingen, ambtelijke opdrachten en dergelijke.

De omschrijvingen blijven vrij algemeen en men dient het voornamelijk te zien als het verstrekken van informatie die relevant is voor het gerechtelijk onderzoek of die van aard kan zijn de activiteiten, de persoonlijkheid van de geviseerde entiteit te kaderen, te contextualiseren.

Hierbij dient opnieuw zeer duidelijk in herinnering te worden gebracht dat de leden van de inlichtingendiensten geen opsporingsbevoegdheid hebben, dat zij geen officieren zijn van gerechtelijke politie en dat zij niet handelen onder het gezag van de gerechtelijke overheid.

Dit betekent met andere woorden dat in het kader van de technische bijstand de leden van de inlichtingendiensten uiteraard niet operationeel kunnen worden ingezet om onder leiding van de Procureur des Konings of de onderzoeksrechter bevoegdheden te gaan gebruiken die eigen zijn aan de inlichtingendiensten.

75. Alhoewel hier dient te worden aangestipt dat deze COL, zoals trouwens de overige, niet publiek is. 
Alhoewel deze problematiek de lege lata niet zo belangrijk is, zou hierin verandering kunnen komen wanneer de BIM-wetgeving in voege treedt.

De vrees werd inderdaad meermaals geuit tijdens de besprekingen in de senaat dat de inlichtingendiensten zouden gebruikt (misbruikt) worden door de gerechtelijke overheden om hun eigen bevoegdheden aan te wenden ten bate van een gerechtelijk onderzoek. Zo zou, wordt dan voorgehouden, met name de telefoontap waarover de inlichtingendiensten beschikken kunnen gebruikt worden met een gerechtelijke finaliteit en in omstandigheden waarin de eigen gerechtelijke telefoontap niet mogelijk zou zijn.

Eerst en vooral dient te worden onderstreept dat uitgaan van een dergelijk scenario een bewuste en moedwillige miskenning zou inhouden, zowel door de gerechtelijke overheden als door de inlichtingendiensten, van hun respectievelijke legale opdrachten en bevoegdheden en derhalve onwettig zou zijn.

Deze vrees lijkt ons vooralsnog ongegrond in de mate dat de inlichtingendiensten bijzonder hechten aan hun eigen en specifieke finaliteit en zich dus niet zouden lenen tot een afwending van hun bevoegdheden.

Daarenboven dient er toch gewezen te worden op de in de op stapel staande wetgeving ingegebouwde controles die, met name voor de meest intrusieve methodes, waaronder de telefoontap, een zeer dwingend systeem van toezicht en voorafgaandelijke controle hebben ingesteld.

Er mag herinnerd worden aan het gegeven dat de uitzonderlijke methoden slechts kunnen worden ingezet mits een voorafgaandelijke toelating van een commissie bestaande uit drie magistraten, terwijl voor de specifieke methoden een gemotiveerde schriftelijke beslissing van het diensthoofd noodzakelijk is en een kennisgeving aan de commissie.

Zoals reeds gesteld kan deze commissie op om het even welk ogenblik haar controle uitoefenen en heeft ook het Comité I een algemene a posteriori toezichtsbevoegdheid.

Het vooropstellen of insinueren van een scenario waarin gerechtelijke overheden en de verantwoordelijken van de inlichtingendiensten desondanks hun bevoegdheden zouden miskennen lijkt ons dus eerder een intentieproces te zijn.

\subsection{Samenloop van inlichtingenonderzoek met opsporings- en gerechtelijk onderzoek}

De eigen finaliteiten van de inlichtingendiensten en de politie- en gerechtelijke diensten enerzijds en de toename van de strafrechterlijke incriminaties en de proactieve recherche anderzijds, hebben tot gevolg dat in bepaalde gevallen deze onderscheiden diensten zich, vanuit hun eigen finaliteit weliswaar, kunnen bezighouden met dezelfde gebeurtenissen.

Betekent dit evenwel dat de taak van de inlichtingendienst ophoudt vanaf het ogenblik dat over dezelfde feiten een opsporings- of gerechtelijk onderzoek wordt gevoerd?

Ons inziens is het antwoord daarop negatief. 
Het Comité I stelt, ons inziens ten onrechte, ${ }^{76}$ dat het binnen de Veiligheid van de Staat 'gebruikelijk zou zijn dat, zodra het dossier een gerechtelijk karakter heeft, deze dienst het dossier niet langer opvolgt'. Er wordt om dit standpunt te staven verwezen naar een verklaring van toenmalig administrateur-generaal Dassen, maar wanneer men zijn bewering analyseert dan blijkt daaruit dat er gesteld wordt dat 'een gerechtelijk onderzoek aan de gang was aangaande deze zaak en dat het in alle opzichten diende vermeden te worden dat er een parallel onderzoek door onze dienst zou gevoerd worden'.77

Het voeren van parallelle onderzoeken is uiteraard niet aangewezen, maar dit houdt geenszins in dat de inlichtingendienst de bevoegdheid tot onderzoek zou verliezen tengevolge van het bestaan van een gerechtelijk onderzoek.

De reeds aangehaalde COL I2/2005 is op dit vlak bijzonder duidelijk en stelt dat het feit dat er een strafonderzoek loopt en dat de VSSE/ADIV daaraan hun technische medewerking verlenen, niet belet dat de inlichtingendiensten in het kader van hun eigen opdrachten dezelfde persoon mogen blijven volgen. Wel wordt vooropgesteld dat er duidelijke werkafspraken dienen te worden gemaakt met het oog op de coherentie en het bundelen van alle nuttige informatie.

Deze problematiek is in België nog vrij onaangeroerd gebleven omwille van het feit dat de inlichtingendiensten, ingevolge de beperkte methodes waarover ze totnogtoe beschikken, niet zo vaak met een dergelijke situatie worden geconfronteerd.

Veel kan daarenboven momenteel worden opgevangen via het systeem van de technische bijstand.

Het debat zou echter in de toekomst aan belang kunnen inwinnen, omdat de inlichtingendienst over veel diepgaandere methoden zal kunnen beschikken dan diegene die ze momenteel aanwendt en het dus perfect denkbaar is dat een inlichtingendienst, die op de lange termijn werkt en geïnteresseerd is in de evolutie van mechanismen en relaties, blijft doorwerken op een fenomeen,waarvan een onderdeel, namelijk het verzamelen van bewijzen en het bestraffen van individuele daders behoort tot de interessesfeer van de gerechtelijke diensten.

Ietwat doorgaand hierop zou men zelfs kunnen stellen dat het vanuit het inlichtingenwerk bijzonder leerrijk en interessant zou kunnen zijn na te gaan welk de impact is op de evolutie van een beweging of vereniging van het instellen van een gerechtelijk onderzoek en de veroordeling van bepaalde personen.

Deze problematiek is natuurlijk zeer intrinsiek verbonden met deze van de overgang van informatie van het inlichtingenwerk naar het gerechtelijk werk, waarbij het debat ons inziens wordt vervuild door de veronderstelling dat de politionele en gerechtelijke autoriteiten de bevoegdheden van de inlichtingendiensten zouden instrumentaliseren, om niet te zeggen misbruiken, omdat de drempelvoorwaarden tot instellen van specifieke en uitzonderlijke methoden op inlichtingenvlak lager zou liggen dan die op gerechtelijk vlak.

76. Vast Comité van Toezicht op de Inlichtingendiensten, Activiteitenverslag 2004, I29.

77. Activieteitenverslag 2003, I9I. 
Hetgeen waarvoor hier wordt gevreesd zijn de zogenaamde U-turn constructies ${ }^{78}$ waarbij er eigenlijk een combine zou op touw worden gezet tussen de de opsporingsdiensten en de inlichtingendiensten om de strikte voorwaarden waaraan hun eigen bevoegdheden zijn onderworpen, te omzeilen.

Zoals reeds uiteengezet lijkt dit eerder op een intentieproces dat wij ten stelligste willen verwerpen en het wil ons voorkomen dat een gerechtelijke overheid zich uiteraard niet tot dergelijke praktijken zou laten verleiden en dat een inlichtingendienst, mocht toch een dergelijk verzoek worden gesteld, dit niet zou inwilligen.

Deze problematiek is ook in Nederland 79 bekend en gaf er aanleiding tot een aantal belangwekkende arresten waarvan de motivatie ook in Belgisch recht zou kunnen gelden:

'Het hof leidt hieruit af dat BVD en justitie ieder voor zichzelf onderzoek kunnen doen - en ook kunnen blijven doen - naar personen of groeperingen indien daartoe, vanuit hun respectieve preventieve en repressieve taken bezien, aanleiding bestaat. De wetgever heeft in de WIV 2002 (evenals in eerdere wetgeving, zie artikel 20 van de 'oude' WIV) een strikte scheiding van taken en bijbehorende bevoegdheden beoogd, naast uitwisseling van informatie tussen BVD en justitie die vanuit een oogpunt van effectieve taakuitvoering van de diensten geboden is. Naar 's hofs oordeel brengt die strikte scheiding geenszins mee dat de BVD zou moeten terugtreden indien justitie gaat opsporen (of anderszins); wél zullen BVD en justitie hun bevoegdheden uitsluitend met het oog op de vervulling van de eigen taak moeten blijven uitoefenen - en gaat het dus bijvoorbeeld niet aan dat justitie grenzen die aan de eigen opsporingsbevoegdheid zijn gesteld omzeilt door de BVD háár bevoegdheden ten behoeve van de strafvordering te laten uitoefenen en de opbrengst daarvan via de landelijk terreurofficier van justitie in het strafrechtelijk onderzoek te laten inbrengen. Maar van een dergelijk handelen is in de onderhavige informatie was er voor de BVD immers alle aanleiding de groepering in kwestie te blijven volgen. De stelling dat een parallel onderzoek van BVD naast justitie niet toegelaten zou zijn en/of dat voortgezette informatie-uitwisseling dan ontoelaatbaar is, vindt geen steun in het recht. Het verweer wordt mitsdien verworpen.'

In België wordt de situatie nog bemoeilijkt door de regel van de verplichte aangifte van misdrijven en de overdracht van nuttige informatie aan de gerechtelijke overheden in toepassing van artikel ig WIV.

Het Comité I stelt met name ${ }^{80}$ dat zelfs indien een inlichtingendienst zijn werk verricht vanuit zijn eigen finaliteit en met inachtneming van haar eigen bevoegdheden, dit probleem in België blijft bestaan. Enerzijds moet de inlichtingendienst elk misdrijf melden (art. 29 Sv) en anderzijds kan hij de inlichtingen die nuttig zijn

78. B. Van Geebergen en D. Van Daele, 'Geheime (?) dienste Over de noodzaak van een ernstig debat over de bijzondere inlichtingenmethoden en de rol van de inlichtingen- en veiligheidsdiensten in de opsporing', De orde van de dag, juli 2008, aflevering 42, 30.

79. Arrest Eik, geciteerd in het Activiteitenverslag van het Comité I, 2004, 130.

80. Comité I, Activiteitenverslag 2004, I30. 
voor de gerechtelijke overheden delen (art. I9 wet op de inlichtingendiensten). Zeker indien bijkomende bevoegdheden toegekend worden aan de inlichtingendiensten, zal die problematiek zich nog scherper stellen.

Zo zou het kunnen dat een verdachte door een onderzoeksrechter omwille van een wettelijke belemmering niet mag worden afgeluisterd, maar dat de betrokkene, conform de finaliteit en de legaliteit van de inlichtingendienst, wordt afgeluisterd en deze inlichtingendienst dan op grond van de verplichting van artikel $29 \mathrm{~Sv}$ of op basis van artikel ig WIV de gegevens doorgeeft aan het gerecht.

Omgekeerd kan het gerecht wanneer het bepaalde gegevens heeft deze melden aan de Veiligheid van de Staat aangezien de problematiek kadert binnen haar bevoegdheden,waarop de inlichtingendienst een onderzoek voert en de resultaten daarvan op zijn beurt aan het gerecht meldt.

Dergelijke werkwijze roept bij het Comité de vraag op of de Veiligheid van de Staat dan niet de facto ingeschakeld in een gerechtelijk onderzoek en of de verdediging dan geen punt zou hebben wanneer zij stelt dat bepaalde rechtswaarborgen geen zin meer hebben?

Ons inziens moet men hier toch wel degelijk een onderscheid gaan maken.

Indien de inlichtingendienst niet louter vanuit haar eigen finaliteit heeft gewerkt, met andere woorden indien er een afwending van de bevoegdheden zou zijn, dan kan men uiteraard de onrechtmatigheid van het bewijs inroepen. Maar quid wanneer de aanwending van de middelen volkomen legaal, overeenkomstig de bevoegdheden en met respect van de finaliteiten is geschied?

Wij stellen ons de vraag op welke basis men een onregelmatigheid zou kunnen vaststellen in de door het Comité I vooropgestelde scenario's: de gerechtelijke overheden blijven binnen hun bevoegdheidsattributies, de inlichtingendiensten eveneens en bij de aangifte van de strafbare feiten of bij de overmaking van nuttige informatie wordt de verplichting van artikel 29 Sv nageleefd of de regeling van artikel i9 WIV.

Daar waar men,zoals reeds uiteengezet geen intentieproces mag voeren en geen kwaad opzet vermoeden, lijkt het evident dat men niet kan voorhouden dat een correcte toepassing van de diverse wetsbepalingen een schending van de wet met zich zou brengen.

Daar waar de hierboven uiteengezette problematiek kadert in de overgang van informatie van het inlichtingenniveau naar het gerechtelijk niveau en dus valt onder de samenwerking, medewerking en technische bijstand tussen de diensten, voegt de op stapel staande BIM-wetgeving daar een eerder paradoxaal nieuw element aan toe.

Het wetsvoorstel voegt inderdaad een artikel $13 / 2$ in de WIV dat luidt als volgt:

'De inlichtingen- en veiligheidsdiensten waken erover geen onderzoeken te voeren die een bewuste aantasting uitmaken van de bevoegdheden van de procureur des Konings of de onderzoeksrechter of die het goede verloop van opsporingsonderzoeken of gerechtelijke onderzoeken kunnen schaden. 
Wanneer een inlichtingen- en veiligheidsdienst een onderzoek instelt dat een weerslag kan hebben op een opsporings- of gerechtelijk onderzoek mag de inlichtingen- en veiligheidsdienst die de in artikel $18 / 2$ bedoelde methoden voor het verzamelen van gegevens aanwendt, dit gerechtelijk- of opsporingsonderzoek niet schaden.

De inlichtingen- en veiligheidsdienst brengt de commissie hiervan op de hoogte. De commissie neemt een beslissing of, en volgens welke modaliteiten, de inlichtingenen veiligheidsdienst het onderzoek kan voortzetten, in overleg met het federaal parket en het diensthoofd van de betrokken dienst. De commissie brengt het Vast Comité I op de hoogte van zijn beslissing. De inlichtingen- en veiligheidsdienst voert zijn opdracht uit overeenkomstig de beslissing van de commissie. De commissie ziet toe op de naleving van zijn beslissing.'

Dit artikel wekt op meerdere vlakken verwondering op.

Allereerst spreekt er een grondig wantrouwen uit ten opzichte van de inlichtingendiensten die hier worden 'verdacht' van een mogelijke bewuste aantasting van de bevoegdheden van de gerechtelijke overheden.

Ten tweede lijkt het ook de bevestiging te zijn dat in de finale appreciatie van de primauteit tussen staatsveiligheid en strafvordering in België de strafvordering overheerst.

Een radicaal tegengesteld uitgangspunt geldt in dat opzicht in Nederland alwaar het belang van de staatsveiligheid prevaleert boven het belang van de strafvordering. ${ }^{8 \mathrm{r}}$

Het lijkt ons ook niet logisch dat in de afweging de vervolging en mogelijke bestraffing van individuele daders zwaarder weegt dan het belang van de vrijwaring van de interne en externe veiligheid van de staat en de democratische rechtsorde.

Kenschetsend is ook het feit dat de omgekeerde hypothese, met name die waarin een opsporings- of gerechtelijk onderzoek een inlichtingenonderzoek zou aantasten, zelfs niet in ogenschouw wordt genomen.

Tot slot roept dit artikel ook een zeer ingewikkelde praktische vraag op, met name hoe de inlichtingendiensten op de hoogte kunnen zijn van alle lopende opsporingsonderzoeken en gerechtelijke onderzoeken waarmee zij desgevallend in conflict zouden kunnen geraken.

\subsection{De problematiek van de classificatie}

In tegenstelling tot hetgeen geldt in een aantal ons omringende landen ${ }^{82}$ en ondanks de algemene titel van dit preadvies dient erop gewezen te worden dat de notie 'staatsgeheim' als dusdanig in België niet bestaat.

De informatie die afkomstig is van inlichtingendiensten wordt beheerst door de wet van II december 1998 betreffende de classificatie en de veiligheidsmachtigingen,

8I. Kamerstukken II 2003/04,29743, nr.3, p.I.

82. In Nederland wordt de term gebruikt in de wet van 5 april I95I. In Frankrijk bestaat de term secret d'état wel en worden er trouwens ook nog een aantal andere uitdrukkingen gebezigd die in meer of mindere mate gewag maken van een specifiek beschermd geheim (secret défense). 
veiligheidsattesten en veiligheidscertificaten. ${ }^{8}{ }^{3}$ Informatie van de Veiligheid van de Staat kan derhalve aangeleverd worden onder verschillende vormen, afhankelijk van de aard van de inlichtingen die erin worden vermeld, de manier waarop deze inlichtingen werden bekomen en de bescherming die zij om diverse redenen - bronbescherming, operationele motieven of regel van de derde dienst - vereisen.

De informatie kan dus, al naargelang het geval, hetzij niet geclassificeerd zijn of bekleed zijn met één van de drie bij wet bepaalde classificaties, te weten vertrouwelijk, geheim of zeer geheim.

De classificatie impliceert ook dat, in principe, de informatie slechts kan worden meegedeeld aan iemand die beschikt over een veiligheidsmachtiging van hetzelfde niveau als de classificatie.

Artikel 8 Classificatiewet: 'Niemand heeft toegang tot geclassificeerde informatie, documenten of gegevens, materieel, materialen of stoffen, tenzij hij houder is van een overeenstemmende veiligheidsmachtiging en voor zover de kennisname en de toegang noodzakelijk zijn voor de uitoefening van zijn functie of zijn opdracht, onverminderd de eigen bevoegdheden van de gerechtelijke overheden en die van de Cel voor financiële informatieverwerking.'

Artikel Io Classificatiewet: 'Geclassificeerde informatie, documenten of gegevens, materieel, materialen of stoffen mogen slechts worden aangewend, zoals bedoeld in artikel 4, mits toelating van de auteur van de classificatie of zijn hiërarchische overste of, in de gevallen door de wet bepaald, onverminderd de eigen bevoegdheden van de gerechtelijke overheden.'

De vraag die zich dus stelt is te weten welk gevolg het aanbrengen van een classificatie heeft?

Dit probleem stelt zich uiteraard in het algemeen met geclassificeerde informatie van de inlichtingendienst, maar het is bijzonder acuut in het geval van het eventueel gebruik in rechte dat van dergelijke informatie zou kunnen worden gemaakt.

In principe mogen deze gegevens immers niet worden overgemaakt aan personen die niet over de vereiste veiligheidsmachtiging beschikken en mogen ze niet worden aangewend, verspreid of meegedeeld aan anderen, zonder toelating van de auteur van de classificatie.

In die optiek zou deze regeling zelfs een uitzondering vormen op artikel 29 Sv vormen, maar de wet heeft bepaald dat deze regeling niet geldt ten aanzien van 'gerechtelijke overheden'. ${ }^{8}$

Onder gerechtelijke overheden dienen te worden begrepen de parketmagistraten en de onderzoeksrechters, alhoewel in principe elke gerechtelijke overheid hierdoor is geviseerd, maar het lijkt uiteraard evident dat hier toepassing wordt gemaakt van het need to know-principe.

Parketmagistraten beschikken derhalve van rechtswege over de toelating om geclassificeerde informatie in te kijken en te gebruiken, maar door de classificatie

83. Wet van II december I998, B.S., 7 mei 1999 hierna Classificatiewet.

84. Deze overheden werden immers in de tekst als uitzondering opgenomen om de toegang van magistraten tot deze gegevens mogelijk te maken in het kader van een opsporings- of gerechtelijk onderzoek; zie ter zake Parl.St. Kamer, I997-I998, II93/6,5 en II93/8,5. 
kunnen zij ze niet meedelen aan bijvoorbeeld de politiediensten belast met het eigenlijke onderzoek op het terrein, tenzij deze in het bezit zou zijn van de nodige veiligheidsmachtiging. 85

Het probleem van de geclassificeerde nota's hangt uiteraard zeer nauw samen met de bestemming die deze nota's uiteindelijk gaan krijgen en is ook intrinsiek verbonden met de problematiek van het gebruik in rechte en de bewijswaarde van gegevens verstrekt door een inlichtingendienst.

De inlichtingendiensten kunnen inderdaad twee soorten nota's maken: de zuiver informatieve nota die het openbaar ministerie toelaten met volle kennis van zaken bepaalde beslissingen te nemen binnen hun bevoegdheidsdomein en de operationele nota, die dan betrekking heeft op een welbepaald strafdossier.

Daar waar de eerste kan geclassificeerd zijn, is de tweede bestemd om te belanden in het open strafdossier, aangezien ze deel uitmaakt van de procedure. In de mate dat stukken die deel uitmaken van het strafdossier kunnen worden geraadpleegd door alle partijen in het geding, volgt hier noodzakelijkerwijze uit dat deze gegevens niet mogen geclassificeerd zijn, aangezien bepaalde personen die ze zouden raadplegen (verdachten, advocaten, burgerlijke partijen) uiteraard niet zullen beschikken over een veiligheidsmachtiging.

Derhalve vraagt het parket aan de inlichtingendienst om gegevens die belangrijk zijn voor een gerechtelijk onderzoek of een vervolging eerst te declassificeren.

De vraag die gesteld wordt is waarom de gegevens afkomstig van de inlichtingendienst in sommige gevallen worden geclassificeerd.

Eerst en vooral is er het principe dat fundamenteel is voor een inlichtingendienst met name de bescherming en afscherming van menselijke bronnen. Voor de Veiligheid van de Staat is dit des te belangrijker in de mate dat, bij afwezigheid totnogtoe van bijzondere inlichtingenmethoden, het gebruik van menselijke bronnen primordiaal is voor de dienst.

Artikel 29 Sv verplicht in principe ook de identiteit van de getuige of de aangever van strafbare feiten aan de procureur mee te delen. Maar anderzijds rust er op de leden van inlichtingendiensten de plicht om over 'de veiligheid van de gegevens die op de menselijke bronnen betrekking hebben' te waken.

Indien de bron om anonimiteit verzocht heeft, vormt de onthulling van diens identiteit zelfs een misdrijf.

Artikel I8 WIV stelt: 'In de uitoefening van hun opdrachten kunnen de inlichtingen- en veiligheidsdiensten een beroep doen op menselijke bronnen. In dat geval, moeten die diensten waken over de veiligheid van de gegevens die op de menselijke bronnen betrekking hebben en over de inlichtingen die ze mededelen.'

Artikel 43 WIV luidt als volgt: 'Onverminderd artikel 458 van het Strafwetboek en de artikelen 48 en 5 I van de wet van 18 juli I99I tot regeling van het toezicht op

85. Hetgeen uiteraard het geval is voor een aantal politiemensen waarmee het Federaal Parket zeer nauw in contact staat. De problematiek van het gebruik van de geclassificeerde nota's wordt geregeld in de COL $12 / 2005$. 
politie- en inlichtingendiensten: (...) $3^{\circ}$ wordt gestraft met de straffen bepaald in het $2^{\circ}$, de agent of de persoon bedoeld in artikel 36 die de identiteit onthult van een persoon die om anonimiteit verzoekt.'

Het is allereerst van belang erop te wijzen dat de uitdrukking 'de veiligheid van de gegevens die op menselijke bronnen betrekking hebben' niet gelijkstaat met de veiligheid van de menselijke bron. Evident is de fysieke integriteit van de bron een in overweging te nemen element, maar naast anderen, zoals de bescherming van het sociaal of familiaal leven.

Het lijkt ook vanzelfsprekend dat de inlichtingendienst zelf belang heeft bij het niet bekendmaken van zijn informantenpositie.

Bij het beantwoorden van de vraag hoe deze geheimhoudingsverplichting zich alsdan verhoudt tot de aangifteverplichting moet men op het eerste gezicht een onderscheid maken tussen de informant die expliciet om anonimiteit verzocht en diegene die dit niet deed. Beide bepalingen zijn immers niet op elkaar afgestemd en moeten afzonderlijk worden bekeken.

Artikel I8 werd immers door de Senaat bij wijze van amendement toegevoegd, zonder de koppeling te maken met de reeds opgenomen verplichting uit artikel 43.

Artikel I8 wou een 'daadwerkelijke vertrouwensovereenkomst ${ }^{\prime} 6$ instellen tussen elke informant en het lid van de inlichtingendienst, ook al verzocht hij niet om anonimiteit. Het was de bedoeling dit vertrouwensbeginsel vorm geven door de identiteit een classificatie te geven. Die piste werd niet weerhouden omdat men in de Kamer op dat ogenblik reeds de Classificatiewet had gestemd.

Concreet betekent dit dat de verplichting uit artikel I8 alleen kan nagekomen worden door de gegevens over de identiteit te classificeren. Op dat ogenblik vallen we terug in de situatie waarbij alleen de parketmagistraat toegang heeft tot de identiteit van de informant.

Heeft de informant om anonimiteit verzocht dan kan men zich de vraag stellen of deze specifieke, strafrechtelijk gesanctioneerde verplichting primeert op de niet strafrechtelijk gesanctioneerde aangifteplicht. Er zijn argumenten aan te halen om deze stelling te ondersteunen (zo is er bijv. het belang dat de wetgever hechtte aan het bronnengeheim voor de werking van de dienst).

Anderzijds is het zo dat deze strafbepaling werd ingevoerd 'onverminderd artikel 458 van het Strafwetboek' zodat de identiteit van de informant bij een getuigenis in rechte niet volledig beschermd is (het lid van de inlichtingendienst beslist zelf of hij de naam kenbaar maakt of niet).

Indien men aanvaardt dat het lid van de inlichtingendienst de identiteit ook niet aan het parket kenbaar mag maken, dan blijft de verplichting om melding te doen van het misdrijf. Hij moet er zich alleen voor hoeden de identiteit van zijn informant kenbaar te maken. In het andere geval zal de identiteit alleen kunnen beschermd worden via een classificatie.

86. Parl. St., Senaat, I997-98, 758/3, II. 
Een andere fundamentele regel van het inlichtingenwerk is de zogenaamde derdenregel of regel van de derde dienst. Deze regel houdt in dat een inlichting die door een officiële dienst van een staat aan een officiële dienst van een andere staat wordt verstrekt eigendom' blijft van de Staat die de inlichting verstrekt.

Concreet betekent dit dat het gebruik van dat gegeven beperkt is tot het doel waarvoor de inlichting wordt verstrekt en dat het gegeven niet zonder akkoord van de verstrekker aan derden mag overgemaakt worden.

Het gaat hier om een fundamentele regel in de verhoudingen en de samenwerking tussen inlichtingendiensten, die door alle diensten wordt gekoesterd en die werkelijk één van de hoekstenen vormt van de onderlinge samenwerking en die op hetzelfde niveau dient te worden gesteld als de bescherming van bronnen.

De miskenning van deze regel zou onvermijdelijk tot gevolg hebben dat de dienst die zich eraan bezondigde zich binnen de kortste keren zou afsnijden van informatie afkomstig van zusterdiensten. Dit is een rampzalig scenario voor elke inlichtingendienst, maar neemt nog grotere dimensies aan voor een dienst die, tengevolge van de afwezigheid van bijzondere methoden,ten zeerste aangewezen is op deze verstrekte informatie.

Quid derhalve wanneer de door de derdenregel gedekte informatie, hetzij de aanduiding bevat van misdrijven, hetzij van belang is voor een lopend strafdossier?

Mag een inlichtingendienst dan weigeren informatie van buitenlandse correspondenten door te spelen?

Het Comité I is alleszins de mening toegedaan dat de derdenregel op gespannen voet staat met de letter van de wet van artikel $29 \mathrm{~Sv} .{ }^{87}$

Hetzelfde probleem stelt zich trouwens met de classificaties aangebracht door een derde dienst. Ook hier oordeelt het Comité I dat zuiver juridisch gezien een classificatie aangebracht door een buitenlandse dienst niet tegenstelbaar zou zijn in een Belgische strafprocedure,maar in feite heeft dit weinig belang, aangezien de ontvangende dienst de classificatie zal hernemen op basis van de nationale wetgeving.

In de praktijk kan evenwel worden vastgesteld dat vele van deze problemen kunnen worden opgelost op een pragmatische wijze, tengevolge van de goede contacten die diensten die al jarenlang samenwerken hebben opgebouwd. Gegevens die werkelijk van cruciaal belang zouden zijn zullen meegedeeld worden na toelating van de genererende dienst of na de classificatie, in zijn geheel of gedeeltelijk.

Men kan zich trouwens de vraag stellen, zowel voor de problematiek van de bronbescherming als van de bescherming van de regel van de derde dienst, in welke mate de oorsprong van de informatie een relevant gegeven is in de meeste gevallen.

De lege ferenda dient verwezen te worden naar een artikel dat wordt ingevoerd door de BIM-wetgeving en dat eveneens betrekking heeft op de problematiek van de declassificatie.

87. Vast Comité I, Activiteitenverslag 2000, 82 en 93. 
Er wordt een artikel I9/I ingevoerd in de WIV dat luidt als volgt:

'Wanneer de aanwending van de specifieke of uitzonderlijke methoden ernstige aanwijzingen aan het licht brengt over het plegen van een misdaad of wanbedrijf of, op grond van een redelijk vermoeden wijst op te plegen of reeds gepleegde maar nog niet aan het licht gebrachte strafbare feiten, brengen de betrokken diensten dit onverwijld ter kennis aan de commissie met het oog op de toepassing van artikel 29 van het Wetboek van strafvordering. Deze commissie onderzoekt de verzamelde gegevens ongeacht de wijze waarop ze vastgelegd werden.

Indien de commissie het bestaan vaststelt van ernstige aanwijzingen die kunnen leiden tot het plegen van een misdaad of wanbedrijf of van een redelijk vermoeden van te plegen of reeds gepleegde maar nog niet aan het licht gebrachte strafbare feiten, stelt de voorzitter daarvan een niet geclassificeerd proces-verbaal op. Dit proces-verbaal wordt onverwijld overgemaakt aan de procureur des Konings of aan de federale procureur, nadat het diensthoofd vooraf gehoord werd over de voorwaarden van deze overmaking.

Dit proces-verbaal dient te preciseren in welke context de inlichtingenopdracht heeft plaatsgevonden, welk doel werd nagestreefd door de betrokken inlichtingen- en veiligheidsdienst, in welke context de ernstige aanwijzingen werden verzameld en die relevant zijn voor een eventuele gerechtelijke finaliteit.

Dit proces-verbaal mag niet de exclusieve grond, noch de overheersende maatregel zijn voor de veroordeling van een persoon. De elementen vervat in dit proces-verbaal moeten in overheersende mate steun vinden in andere bewijsmiddelen.

De procureur des Konings of de federale procureur licht de voorzitter van de commissie in over de gevolgen die aan de overmaking van het proces-verbaal worden gegeven. De voorzitter van de commissie licht op zijn beurt het diensthoofd van de betrokken dienst in.'

\section{Gebruik van informatie in strafproces en bewijskracht}

\section{I Algemene opmerkingen}

De problematiek van het gebruik van informatie afkomstig van inlichtingendiensten in het strafproces en de bewijskracht die eraan wordt verleend is waarschijnlijk de meest complexe en de meest delicate van allemaal, omdat we hier eigenlijk te maken hebben met een 'schok van twee werelden'. Inlichtingenwerk gebeurt per definitie op een discrete, niet openbare en niet voor publiciteit vatbare manier, terwijl een strafproces contradictoir dient te gebeuren, in de openbaarheid en, zeker wanneer het zich handelt om zaken van terrorisme, met een grote publieke en mediatieke belangstelling.

Daarenboven dient men in deze ook rekening te houden met de nationale regels met betrekking tot de strafvordering, de problematiek van het rechtmatig bewijs, de principes vervat in het EVRM in verband met de wapengelijkheid, de loyauteit, het eerlijk proces. 
De problematiek van het bewijs en de bewijskracht is in Belgisch strafprocesrecht vrij ingewikkeld en heeft daarenboven het voorwerp uitgemaakt van een zeer belangrijke evolutie in de afgelopen jaren in de cassatierechtspraak met betrekking tot het onrechtmatig bewijs. ${ }^{88}$

Het Hof van Cassatie is inderdaad geëvolueerd van een volledig verbod op gebruik van onrechtmatig bewijs, naar een toelating tot gebruik ervan behalve wanneer de onrechtmatigheid voortspruit uit de niet-naleving van een op straffe van nietigheid voorgeschreven vormvereiste, een onrechtmatigheid die de geloofwaardigheid van het bewijs aantast en een gebruik van bewijs dat de regels van het eerlijk proces aantast.

Ook de rechtspraak van het EVRM dient hierbij dus in aanmerking genomen te worden en ook hier zijn er een aantal evoluties te onderkennen.

Het algemeen principe in verband met de bewijsvoering in Belgisch strafprocesrecht is dat de bewijsvoering vrij is.

Hierop bestaan evenwel een aantal uitzonderingen: de specifieke bewijswaarde van bepaalde processen-verbaal (zie hierna), de getuigenis onder volledige anonimiteit (art. I8gbis,\$3 Sv), de verklaringen gedaan per telefoonconferentie (art. II2bis,\$6 en 158 ter, $\$ 5 \mathrm{~Sv}$ ), de verklaringen gedaan per videoconferentie of via een gesloten televisiecircuit met wijziging van beeld en spraak (art. I58bis,\$6 en 317quater,\$ 6 Sv) en de regels met betrekking tot het zwijgrecht van de beklaagde.

\subsection{Informatie van inlichtingendiensten als bewijs of als start van een gerechtelijk- of opsporingsonderzoek}

Het principe van de vrijheid in de bewijsvoering betekent dat, met betrekking tot stukken, alle documenten, processen-verbaal, nota's kunnen worden gevoegd als ze van nut zijn voor het bewijs van bepaalde misdrijven.

De inlichtingen die een inlichtingendienst overmaakt, hetzij op eigen initiatief, hetzij op verzoek, hetzij in het kader van artikel 29 Sv kunnen derhalve worden gebruikt in een opsporings- of gerechtelijk onderzoek en dus later ook als mogelijk bewijs van een misdrijf.

Nota's van de VSSE of de ADIV kunnen dus gebruikt worden als bewijsmateriaal en volgen op dat ogenblik de algemene regels met betrekking tot de bewijskracht, hetgeen betekent dat deze documenten geen bijzondere strafrechtelijke waarde hebben maar gelden ten titel van inlichting. Ook processen-verbaal van de politiediensten hebben trouwens doorgaans geen bijzondere bewijskracht, tenzij de wet het anders bepaalt. ${ }^{89}$

Bij de totstandkoming van de organieke wet van 1998 op de inlichtingendiensten was het de wens van de wetgever dat de gegevens van inlichtingendiensten steeds in

88. Zie dienaangaande H.-D. Bosly en D. Vandermeersch, Droit de la procédure pénale, La Charte, 2008, I406-I495.

89. Ten uitzonderlijke titel kent de wet aan sommige processen-verbaal een speciale bewijskracht toe, te weten geldend tot bewijs van het tegendeel of, nog uitzonderlijker, geldend tot aan inschrijving wegens valsheid in geschriften. 
het onderzoeksdossier zouden terechtkomen om zo alle speculaties te vermijden en tot een eerlijk proces te komen:

'Het valt niet te ontkennen dat in het kader van een goede samenwerking tussen de gerechtelijke overheden en de inlichtingen- en veiligheidsdiensten, zowel het openbaar ministerie als de onderzoeksrechter inlichtingen moeten kunnen meedelen aan deze diensten en een beroep moeten kunnen doen op hun gespecialiseerde kennis en informatie.

Dit moet kunnen gebeuren, niet in "een clandestiene" atmosfeer zoals vroeger, maar in een wettelijke en feitelijke transparantie en op basis van officiële schriftelijke stukken die gevoegd worden bij de dossiers en die toelaten aan het openbaar ministerie, aan de onderzoeksrechter, aan de verdediging en aan de rechter ten gronde, om de wettigheid van de bewijsmiddelen en de loyaliteit waarmee ze verzameld werden, te toetsen.' ${ }^{90}$

Ook de COL I2/2005 gaat ervan uit dat,indien het openbaar ministerie ze in een strafprocedure wil gebruiken, de niet-geclassificeerde stukken van de VSSE en ADIV in principe als dusdanig bij het strafdossier kunnen worden gevoegd.

Indien daarenboven het openbaar ministerie de mening is toegedaan dat het opportuun is de documenten niet als dusdanig maar onder een andere vorm te voegen, worden de inlichtingendiensten gevraagd het document aan te passen, zodanig dat zij kunnen rekening houden met 'de bekommernis die aan de basis ligt van de door de parketmagistraat genomen beslissing (oriëntering of splitsing van het onderzoek, bescherming van bronnen...)'.

Eens te meer blijkt uit deze bepalingen dat in België de primauteit gelegd wordt bij het gerechtelijke boven het inlichtingenwerk, maar het houdt ons inziens ook een aantal gevolgen in.

Het openbaar ministerie beslist met name over de opportuniteit van de vervolgingen en wanneer de inlichtingendiensten niet-geclassificeerde inlichtingen overmaken, lijkt het ons dan ook evident dat de verantwoordelijkheid voor hun aanwending bij het openbaar ministerie ligt.

In bepaalde gevallen zal de door de inlichtingendiensten aangeleverde informatie niet direct bruikbaar zijn als bewijsmateriaal maar eerder een vorm van contextualisering inhouden, een soort informatie die het openbaar ministerie moet toelaten een eventuele proactieve recherche op te starten. Het is hetgeen men zou kunnen noemen aansturinginformatie. Moet deze in het dossier terechtkomen?

Vanuit het standpunt bekeken van de VSSE kan men stellen dat indien de dienst informatie meedeelt zonder classificatie, deze uiteraard in het open dossier mag terechtkomen, ook wanneer dit sturingsinformatie zou zijn.

Anderzijds impliceert het verschil in finaliteiten tussen gerechtelijke- en inlichtingendiensten ook dat het openbaar ministerie andere redenen kan hebben om

9o. Parl.St. Senaat, I997-I998, 758/9, 2-3. 
informatie die door de inlichtingendienst gedeclassificeerd werd niet in het open strafdossier te brengen.

Ook in dit geval mag men de inlichtingendienst hiervoor niet aansprakelijk stellen.

Het komt ons trouwens voor dat het Comité I vrij ver gaat wanneer het stelt ${ }^{91}$ dat 'de redenen hiervoor kunnen uiteenlopend zijn: men wil gevoelige informatie afschermen, men wil de gebruikte methode niet compromitteren, men wil de veiligheid van informanten garanderen, men vreest dat de gebruikte methode de toets van de rechtmatigheid niet zal doorstaan...'. Vooral deze laatste 'bekommernis' is problematisch omdat ze tot gevolg kan hebben dat onrechtmatig vastgestelde feiten nadien op een legale manier worden 'vastgesteld'.

De vraag is wie hier geviseerd wordt met 'men'? Spreekt hier niet een totaal misplaatst wantrouwen uit zowel tegenover de gerechtelijke diensten als tegen de inlichtingendiensten, die als het ware verdacht worden van bewuste samenwerking met het oog op het verbergen of witwassen van informatie.

Er mag toch aan herinnerd worden dat er in het kader van de BOM-wetgeving een controle is van een magistraat over de toepassing en aanwending van bijzondere methoden, dat er een gerechtelijke controle is door de kamer van inbeschuldigingstelling over het confidentieel BOM-dossier, dat er in het kader van de BIM-wetgeving een systeem is voor voorafgaandelijke controle en toelating over de specifieke en uitzonderlijke methodes door een college van drie magistraten, die nadien ook nog eens tussenkomen in de opstelling van een gedeclassificeerd proces-verbaal dat dient te preciseren in welke context de inlichtingenopdracht heeft plaatsgevonden, welk doel werd nagestreefd door de betrokken inlichtingendienst, in welke context de ernstige aanwijzingen werden verzameld en die relevant zijn voor een eventuele gerechtelijke finaliteit.

In deze omstandigheden een onwettigheid of een onwettige samenwerking tussen de diensten gaan veronderstellen lijkt ons zeer verregaand, beledigend en grenzend aan paranoia.

Gaat het om geclassificeerde informatie,dan zal uiteraard een oplossing dienen gezocht te worden in de declassificatie, maar met eerbiediging van de fundamentele regels in verband met de bescherming van menselijke bronnen, de derdenregel en de lege ferenda, ons inziens, ook de bescherming van de operationele ingezette middelen.

De declassificatie heeft uiteraard voor gevolg dat in het open dossier gegevens terechtkomen die ontdaan zullen zijn van bepaalde elementen, maar de vraag die hierbij dient gesteld te worden is of dit noodzakelijkerwijze in strijd is met de nationale wetgeving of met het EVRM?

Het Comité I meent dat dit niet te verenigen is met het feit dat er geen rechterlijke controle is op de geclassificeerde gegevens. Allereerst is dit de lege lata al onjuist, vermits het openbaar ministerie, zoals dat gebeurt in de BOM-wetgeving, kan zien

9I. Activiteitenverslag 2004, I34. 
wat er geclassifieerd is en wat er moet gedeclassifieerd worden. Anderzijds is er de lege ferenda een regeling voorzien die deze rechterlijke controle verzekert, zodat dit argument alleszins niet meer valabel is.

Onderliggend ziet men ook de neiging van het Comité I om de classificatie zelf aan te vechten, waarbij er ons inziens vrij vlug gewag wordt gemaakt van een afwezigheid van controle over de classificatie en er geïnsinueerd wordt dat er aan overclassificatie zou worden gedaan met het doel om 'bepaalde praktijken aan controle te onttrekken'..$^{2}$

Ook hier lijkt de uitgangspositie ingegeven door een fundamenteel en ongegrond wantrouwen enerzijds en een streven om zelf de classificatie te kunnen bepalen hetgeen volledig in strijd is met de bepalingen ter zake van de Classificatiewet.

Anderzijds dient erop te worden gewezen dat het openbaar ministerie niet kan verplicht worden om de stukken in zijn bezit over te maken en dat ook uit het EVRM zelf een dergelijke verplichting niet is af te leiden.

Het recht om kennis te nemen van alle bewijselementen van de vervolgende partij is evenwel niet absoluut. In sommige strafrechtelijke procedures kunnen er tegenstrijdige belangen aanwezig zijn, zoals de nationale veiligheid, de noodzaak om getuigen te beschermen of onderzoeksmethoden geheim te houden, die dienen te worden afgewogen tegen de rechten van de beklaagde. In sommige gevallen kan het noodzakelijk zijn om bepaalde bewijselementen geheim te houden voor die partij teneinde de fundamentele rechten van andere personen of een behartenswaardig

De inmenging in de rechten van de verdediging kan echter enkel worden verantwoord indien zij strikt evenredig is met het belang van de te bereiken doelstellingen en indien zij wordt gecompenseerd door een procedure die een onafhankelijke en onpartijdige rechter in staat stelt de wettigheid van de procedure te onderzoeken. ${ }^{93}$

Een laatste en meest verregaande hypothese die door het Comité I wordt weerhouden is de situatie waarin blijkbaar de inlichtingendienst zelf informatie zou achterhouden, met andere woorden een toestand waarin de inlichtingendienst zou kunnen verplicht worden informatie die zij oordeelde niet te moeten vrijgeven, uiteindelijk op dwingend bevel van de gerechtelijke overheid te overhandigen.

In Nederland werd hiervoor volgende regeling voorzien: op zijn verzoek krijgt het lid van het openbaar ministerie inzage 'in alle aan de mededeling ten grondslag liggende gegevens die voor de beoordeling van de juistheid van de mededeling noodzakelijk zijn'. (art. 38, lid 3 wet van 7 februari 2002 op de inlichtingen- en veiligheidsdiensten). Anderzijds is het lid van het openbaar ministerie met betrekking tot die gegevens tot geheimhouding verplicht, hetgeen inhoudt dat in Nederland de geheimhouding van de bronnen en de modus operandi voor de AIVD een rechtsplicht is, die ook de informatieverstrekking aan justitie beheerst, hetgeen perfect kadert in de stellingname dat staatsveiligheid primeert over strafrecht.

In Belgïe gaat men uit van een andere filosofie, die zich dan ook uit in zeer indringende maatregelen van het gerecht wanneer het informatie die bij de

92. Activiteitenverslag 2004, 136 .

93. EVRM,arresten Edward t. Verenigd Koninkrijk en Lewis t. Verenigd Koninkrijk, 22 juli 2003 en 27 oktober 2004 . 
inlichtingendiensten berust wil bekomen. De wet op de inlichtingendiensten heeft voorzien in de mogelijkheid om een huiszoeking (art. $38 \mathrm{WIV}$ ) te verrichten bij de inlichtingendiensten om gegevens en documenten in beslag te nemen.

Het is een procedure die zeer uitzonderlijk is en dat ons inziens ook moet blijven, aangezien men op dat ogenblik blijkbaar in de ultieme confrontatie zit tussen twee belangen. Ons inziens kan men via doorsturen van informatie, aanpassen van informatie aan de noden van een gerechtelijk onderzoek, declassificatie van informatie, het merendeel van de inlichtingen die van belang zijn voor een gerechtelijk onderzoek overmaken, zonder dat men in deze extreme situatie dient te belanden.

Indien men ondanks alles toch in dit stadium belandt, dan dringt ons inziens zich toch een reflectiemoment op. Heeft men op dat ogenblik inderdaad niet de grens bereikt waar echt de afweging dient gemaakt te worden tussen het belang van de staat bij een rechtsgang en een desgevallend hoger belang. Indien een inlichtingendienst, ondanks de verschillende mogelijkheden om informatie mee te delen, meent dat ze moet geheim gehouden blijven, 94 dan moet men gaan nadenken of ze manu militari dient te worden in beslag genomen en vrijgegeven.

Hier bereikt men misschien wel de grens tussen transparantie en - alhoewel het begrip niet bestaat - staatsgeheim.

Dat er zelfs in dat geval een controle moet kunnen zijn, of beter gezegd een instantie die in dat geheim deelt, lijkt ons evident. De vraag is - en we zullen ze in het kader van deze studie niet beantwoorden - wie op dat ogenblik de best geplaatste instantie daarvoor is.

Volledigheidshalve vermelden we ook nog dat niets in Belgisch recht belet dat een informatie gegeven door een inlichtingendienst als basis zou kunnen gelden voor het nemen van een dwangmaatregel, aangezien het openbaar ministerie of de onderzoeksrechter in eerste instantie zelf daarover te oordelen hebben.

\subsection{Getuigenis in rechte en beroepsgeheim}

Kan of mag of moet een lid van een inlichtingendienst getuigen in rechte, waaronder begrepen wordt zowel voor de onderzoeksrechter als voor de rechter ten gronde?

En zo ja, wat is of kan of mag de omvang van dat getuigenis zijn?

In het Belgisch strafprocesrrecht bestaat een regeling van gedeeltelijke of volledige anonimiteit, zowel voor de onderzoeksrechter als voor de rechter ten gronde.

De vraag is evenwel of de voorwaarden daarvan die uiteengezet zijn in de artikelen 75 bis en 86bis Sv. wanneer het de fase van het gerechtelijk onderzoek betreft en in artikel I8gbis Sv; voor de rechter ten gronde van toepassing zouden zijn op leden van de inlichtingendiensten die in rechte moeten getuigen.

Het antwoord lijkt ons ter zake negatief te zijn, omdat het zeer zelden zal voorkomen dat een lid van de inlichtingendienst in een situatie zou terechtkomen waarin

94. We spreken hier uiteraard over een legitiem belang tot geheimhouding. 
zijn fysische integriteit zou bedreigd worden in de mate dat het een anonieme getuigenis verantwoordt.

Merken we hier op dat de regeling die geldt voor politiemensen in het kader van de BOM-wetgeving met betrekking tot de anonieme getuigenis niet van toepassing is op de leden van inlichtingendiensten en ook de lege ferenda blijkbaar niet werd voorzien.

Anderzijds heeft dit natuurlijk een reden aangezien de leden van de inlichtingendiensten in tegenstelling tot die van de politie niet aan infiltratie doen.

Merken we hier toch ook op dat, zoals reeds uiteengezet, een volledig anonieme getuigenis op zichzelf de veroordeling van een persoon niet kan gronden noch op een determinerende wijze beïnvloeden en dat ze steeds moet worden onderbouwd door elementen van bewijs die op een andere manier werden bekomen.

Het lid van de inlichtingendienst is in principe gehouden tot het beroepsgeheim voor alle zaken die hij verneemt in het kader van zijn functie. Indien hij echter opgeroepen wordt om in rechte een getuigenis af te leggen, bepaalt hij zelf of hij het geheim kenbaar maakt of niet. De geheimhoudingsverplichtingen die voortvloeien uit artikel 43 van de wet op de inlichtingendiensten gelden immers 'onverminderd artikel 458 van het Strafwetboek'.

Een van de zaken die een lid van de inlichtingendiensten niet zal meedelen is de identiteit van de menselijke bronnen en evenmin de geclassificeerde gegevens.

\section{Eindconclusie}

Tot slot van deze studie dient gesteld te worden dat de problemen waarmee de inlichtingendiensten geconfronteerd worden in hun relatie tot de politie- en gerechtelijke diensten blijkbaar in Nederland en België zeer gelijklopend zijn.

De oplossingen zijn echter op meerdere vlakken verschillend en hebben vooral te maken met enerzijds de radicaal andere invalshoek ten opzichte van de basisrelatie staatsveiligheid versus strafproces en anderzijds ook met de ervaring die Nederland al meerdere jaren heeft met deze problematiek en uiteraard ook met het grondig verschil in cultuur en appreciatie van inlichtingendiensten.

Deze verschillende benadering legt ook uit waarom de oplossingen niet onmiddellijk transponeerbaar zijn tussen de beide landen.

Anderzijds is het ook zo dat, mede tengevolge van de afwezigheid van bijzondere middelen tot vergaring van informatie door de inlichtingendiensten, de problematiek totnogtoe in België vrij onderbelicht is gebleven.

Daar zal hoogstwaarschijnlijk binnen afzienbare tijd verandering in komen op het moment waarop de BIM-wetgeving van kacht wordt. De discussies waartoe deze wetgeving reeds aanleiding heeft gegeven, zowel in de parlementaire cenakels als in academische middens, bij politiediensten, bij gerechtelijke overheden, bij mensenrechtenorganisaties, bij journalisten en in het algemeen in de media, lijkt erop te wijzen dat er een periode zal aanbreken waarin de principes van de wetgeving zullen moeten toegepast, toegelicht, verfijnd en geïnterpreteerd worden. 
Nadien zal er onvermijdelijk ook een evaluatie dienen te gebeuren, zowel op het praktische vlak, waarbij het nut, het gebruik, de resultaten zullen dienen te worden geanalyseerd, alsmede de pijnpunten, om zo desgevallend de wetgeving op bepaalde vlakken te kunnen bijsturen.

Het staat dus buiten kijf dat deze problematiek in de toekomst nog zeer vaak ter sprake zal komen en meer dan waarschijnlijk stof zal zijn tot menige andere bijdragen. 